\title{
MICRO DATA AND THE MACRO ELASTICITY OF SUBSTITUTION
}

\author{
by \\ Ezra Oberfield * \\ Federal Reserve Bank of Chicago
}

and

\section{Devesh Raval * \\ Amazon.com}

CES 12-05

March, 2012

The research program of the Center for Economic Studies (CES) produces a wide range of economic analyses to improve the statistical programs of the U.S. Census Bureau. Many of these analyses take the form of CES research papers. The papers have not undergone the review accorded Census Bureau publications and no endorsement should be inferred. Any opinions and conclusions expressed herein are those of the author(s) and do not necessarily represent the views of the U.S. Census Bureau. All results have been reviewed to ensure that no confidential information is disclosed. Republication in whole or part must be cleared with the authors.

To obtain information about the series, see www.census.gov/ces or contact Cheryl Grim, Editor, Discussion Papers, U.S. Census Bureau, Center for Economic Studies, 4600 Silver Hill Road, Washington, DC 20233, CES.Papers.List@census.gov. 


\begin{abstract}
We estimate the aggregate elasticity of substitution between capital and labor in the US manufacturing sector. We show that the aggregate elasticity of substitution can be expressed as a simple function of plant level structural parameters and sufficient statistics of the distribution of plant input cost shares. We then use plant level data from the Census of Manufactures to construct a local elasticity of substitution at various levels of aggregation. Our approach does not assume the existence of a stable aggregate production function, as we build up our estimate from the cross section of plants at a point in time. Accounting for substitution within and across plants, we find that the aggregate elasticity is substantially below unity at approximately 0.7 . Lastly we assess the sources of the bias of aggregate technical change from 1987 to 1997 . We find that the labor augmenting character of aggregate technical change is due almost exclusively to labor augmenting productivity growth at the plant level rather than relative growth in capital intensive plants.
\end{abstract}

Keywords: Elasticity of Substitution, Aggregation, Bias of Technical Change.

* We would also like to thank Frank Limehouse for all of his help at the Chicago Census Research Data Center. Any opinions and conclusions expressed herein are those of the authors and do not necessarily represent the views of the U.S. Census Bureau, Federal Reserve Bank of Chicago or the Federal Reserve System. All results have been reviewed to ensure that no confidential information is disclosed. All mistakes are our own. 


\section{Introduction}

An aggregate production function lies at the heart of macroeconomic analysis. In a world with heterogeneous firms, however, aggregate production technology is not generically stable unless strong restrictions on firm production technology are satisfied. In this paper, we combine theory with microdata on manufacturing plants to characterize important local features of aggregate technology: the aggregate labor-capital elasticity of substitution and the direction of technical change.

Both the aggregate elasticity of substitution and the bias of technical change determine features of long run growth. In addition, the aggregate elasticity of substitution is a key determinant of how the economy responds to capital taxation, immigration flows, and other determinants of aggregate factors. Because of the importance of these features of aggregate technology, economists have a long history of estimating aggregate production functions.

The usual estimation approach examines how aggregate factor shares respond to changes in factor prices. This approach suffers from two well known issues. First, factor prices and factor augmenting technology together determine factor shares. Any correlation between movements in factor prices and factor augmenting technical change biases time series estimates of the substitution elasticity. ${ }^{1}$ Estimates of the elasticity of substitution depend critically, then, on whether (and how) factor augmenting technical change is modeled. Because of this problem, macroeconomists have not arrived on a consensus on the value of the aggregate substitution elasticity.

More fundamentally, econometric models require stable structural parameters. If the aggregate elasticity of substitution is not stable, estimates using aggregate data will not estimate a deep structural parameter. ${ }^{2}$

Instead, we use theory to infer features of aggregate technology based upon parameters of plant level technology and demand that we estimate. We identify the local aggregate elasticity of substitution using only data on the cross-section of plants at a point in time. By only using the

\footnotetext{
${ }^{1}$ For the last century, the aggregate labor share in the US economy has been roughly two thirds. While a CobbDouglas aggregate production is consistent with this stylized fact, so is any other constant returns to scale production function with labor augmenting technological change.

${ }^{2}$ This point is related to (but distinct from) the critique of Fisher (1969) that without satisfying stringent assumptions one cannot aggregate heterogeneous capital goods into a single capital aggregate. See Fisher and Monz, eds (1992) for a more comprehensive review.
} 
cross-section, we both avoid the pitfalls that come with aggregate time series estimation, and can examine how aggregate production technology has varied over time.

We then obtain a snapshot of an approximate aggregate production function, which allows us to answer several questions: What is the aggregate elasticity of substitution at each point in time? Has this parameter been stable? What are the sources of the bias of aggregate technical change?

We show that the local aggregate elasticity of substitution is a convex combination of the micro elasticity of substitution and the elasticity of demand, which combines both substitution within plants and across plants. ${ }^{3}$ Consumers are more willing to substitute to lower cost goods when demand is more elastic, increasing the scope for substitution across plants. If the elasticity of demand is higher than the micro elasticity of substitution, as we find in US manufacturing, then the aggregate elasticity of substitution is higher than the micro elasticity of substitution.

The weight on the elasticity of demand is proportional to the cost weighted variance of capital shares, a sufficient statistic for the dispersion in factor augmenting productivity. When plants produce at different capital intensities, factor price movements alter relative costs across plants and so give consumers scope to substitute across plants.

We then use the US Census of Manufactures to estimate the elasticity of substitution at various levels of aggregation. We begin by estimating the plant level elasticity of substitution using the approach of Raval (2011), who exploits geographic variation in wages. We back out the elasticity of demand from revenue-cost ratios assuming optimal price setting behavior. ${ }^{4}$

For the manufacturing sector as a whole we estimate that the elasticity of substitution is roughly $0.68 .^{5}$ Our estimate in 1997 is slightly larger than our estimate in 1987, which is mostly attributable to changes in the composition of firms. Among 2 digit industries the the average industry level elasticity is .65. Plants are sufficiently similar that roughly four fifths of substitution between

\footnotetext{
${ }^{3}$ Our work builds on Sato (1967), who derives an analogous formula for a two good economy with perfect competition for each good.

${ }^{4}$ For industries with separate price and quantity data, we can also estimate the elasticity of demand using the approach of Foster et al. (2008), who use variation in average cost to trace out firms' demand curves. We find that for the aggregate elasticity of substitution it makes little difference which methodology is used.

${ }^{5}$ Our estimate is a long run elasticity of substitution between capital and labor, owing to a proper interpretation of our estimates of firm level parameters. This elasticity is then an upper bound on the short run elasticity of substitution, which might be more relevant for interpreting fluctuations at business cycle frequencies. Because the long run elasticity is below unity, the short run elasticity is even further from a Cobb-Douglas benchmark.
} 
capital and labor occurs within individual plants.

Lastly we assess the source of the labor augmenting character of aggregate technological change. We decompose this into a contribution from bias in the direction of technological change at individual plants and shifts in composition due to neutral changes in productivity or demand. For both 1987-1992 and 1992-97, we find that almost all of the aggregate bias can be accounted for by labor augmenting technical change at the plant level.

An important caveat to our current analysis is that we only estimate adjustment on the intensive margin: substitution within and among existing plants. We do not analyze the extensive margin coming from new plants entering the market or existing plants exiting the market, or from biased technical change induced by factor prices. Our approach understates the elasticity of substitution if the composition of entering or exiting plants responds to changes in factor prices.

Our work relates to two strands of the literature. First, a theoretical literature has tried to build up aggregate production technology from micro units. Houthakker (1955), Jones (2005), and Luttmer (2011) study environments in which the choices of individual plants producing with a fixed proportions technology give rise to an aggregate Cobb-Douglas production function. Each paper provides a mechanism for aggregate factor substitution through the extensive margin. Houthakker (1955) assumes that there is a fixed set of firms that face capacity constraints. Factor prices affect each firm's marginal cost, and only firms below the cost cutoff operate. Jones (2005) and Luttmer (2011) assume that every firm faces a common menu of technologies, ranging from more to less capital intensive, that is fixed at a point in time but evolves over time. ${ }^{6}$ As factor prices change, all firms simultaneously switch production technologies. In both environments, the shape of aggregate technology depends heavily on the distribution of available technologies, as Levhari (1968) points out.

Second, an empirical literature has used aggregate time series data to estimate an aggregate production function. ${ }^{7}$ As emphasized by Diamond et al. (1978), it is difficult to separate the elasticity of substitution between capital and labor from factor biased technical change. In general,

\footnotetext{
${ }^{6}$ Putty clay models, as in Johansen (1972), are similar to Jones (2005) except that only entrants can choose from the menu, while incumbents cannot change technologies.

${ }^{7}$ Others, such as Arrow et al. (1961) and Lucas (1969), have also examined industry factor shares using variation in factor prices across states or countries.
} 
researchers have placed strong assumptions on the nature of technical change. In a classic paper, Berndt (1976) finds a unitary elasticity of substitution in the US time series assuming neutral technical change. Antras (2004) and Klump et al. (2007) subsequently find an elasticity of substitution significantly less than unity once they allow for non-neutral productivity growth. ${ }^{8}$ Even with such assumptions, Leon-Ledesma et al. (2010) show that it is difficult to identify the macro elasticity of substitution without using the entire system of equations from the representative firm's maximization problem. However, a systems approach leans even more heavily on the assumption of a stable aggregate production function.

Section 2 contains our theoretical analysis of the aggregation problem, Section 3 our empirical approaches and estimates using production microdata, and Section 4 concludes.

\section{Theory: Aggregation and the Macro Elasticity of Substitution}

In this section, we show how to aggregate heterogenous firms to derive the aggregate elasticity of substitution and aggregate technical change. We first examine a benchmark case of profit maximizing firms in a single industry in Section 2.1. Each firm has a CES production function with capital and labor as inputs and faces an isoelastic demand curve. Firms differ from each other in their productivity levels, and these differences may be non-neutral. From these micro-foundations, we derive the aggregate elasticity of substitution. The aggregate elasticity of substitution is a simple function of the micro elasticities of substitution, elasticity of demand, and a normalized cost weighted variance of firm capital shares.

We then extend this benchmark case to allow multiple industries in Section 2.2 and to include additional inputs such as materials in Section 2.3. In Section 2.4, we show how to derive the bias in aggregate technical change, and decompose this bias into contributions from biased technical change within firms and neutral shifts in composition.

Throughout, we maintain the following assumptions:

\footnotetext{
${ }^{8}$ Antras (2004) models exponential labor augmenting productivity growth and Klump et al. (2007) use a 2 parameter Box-Cox transformation that nests exponential growth.
} 
Assumption 1 (1) All firms produce using constant returns to scale technology; (2) Factor markets are competitive; (3) All firms face isoelastic demand curves, and firms within an industry face a common demand elasticity; (4) All firms maximize profits.

For the within firm margin of adjustment, only the assumptions of competitive factor markets and cost minimization are necessary. The other assumptions greatly simplify our characterization of the between firm margin of adjustment.

\subsection{The Industry Elasticity of Substitution}

For simplicity, first consider an industry composed of firms whose production functions share a common, constant elasticity of substitution between capital and labor, $\sigma_{i}=\sigma$. A firm produces output $Y_{i}$ from capital $K_{i}$ and labor $L_{i}$ using the following CES production function:

$$
Y_{i}=\left[\left(A_{i} K_{i}\right)^{\frac{\sigma-1}{\sigma}}+\left(B_{i} L_{i}\right)^{\frac{\sigma-1}{\sigma}}\right]^{\frac{\sigma}{\sigma-1}}
$$

Productivity differences between firms are factor augmenting: $A_{i}$ is the firm's capital augmenting productivity and $B_{i}$ its labor augmenting productivity. ${ }^{9}$

Each firm also faces the following isoelastic demand curve:

$$
Y_{i}=D_{i} P_{i}^{-\epsilon}
$$

$D_{i}$ is the firm specific level of demand. ${ }^{10}$ The elasticity of demand $\epsilon$ is common to all firms in the industry and is above one, as is required for finite prices. Each firm maximizes profits given its level of demand and factor prices $w$ and $r$ for labor and capital.

Our goal is to characterize how the capital-labor ratio at the industry level changes when relative factor prices change. The industry capital labor ratio is the sum of each firm's capital-labor ratio

\footnotetext{
${ }^{9}$ This specification nests neutral productivity differences.

${ }^{10}$ Demand would be of this form if consumers have Dixit-Stiglitz preferences with an industry aggregate $Y_{n}=$ $\left(\sum_{i \in I_{n}} \tilde{D}_{i}^{\frac{1}{\epsilon}} Y_{i}^{\frac{\epsilon-1}{\epsilon}}\right)^{\frac{\epsilon}{\epsilon-1}}$. In this case $D_{i}=Y_{n} P_{n}^{\epsilon} \tilde{D}_{i}$, where $P \equiv\left(\sum_{i \in I_{n}} \tilde{D}_{i} P_{i}^{1-\epsilon}\right)^{\frac{1}{1-\epsilon}}$ is the ideal price index.
} 
weighted by the firm's share of industry labor:

$$
\frac{K_{n}}{L_{n}}=\sum_{i \in I_{n}} \frac{K_{i}}{L_{i}} \frac{L_{i}}{L_{n}}
$$

We can then decompose the industry elasticity of substitution into a within firm component and between firm component. The within firm component captures the change in factor proportions holding fixed each firm's share of aggregate labor. The between firm component is the change in firm shares of aggregate labor holding each firm's capital-labor ratio fixed. The industry elasticity of substitution then becomes:

$$
\begin{aligned}
-\frac{\partial \ln \left(K_{n} / L_{n}\right)}{\partial \ln (r / w)} & =\frac{1}{\left(K_{n} / L_{n}\right)}\left[\sum_{i \in I_{n}}\left(-\frac{\partial \ln \left(K_{i} / L_{i}\right)}{\partial \ln (r / w)}\right) \frac{K_{i}}{L_{i}} \frac{L_{i}}{L_{n}}+\sum_{i \in I_{n}}\left(-\frac{\partial \ln \left(L_{i} / L_{n}\right)}{\partial \ln (r / w)}\right) \frac{K_{i}}{L_{i}} \frac{L_{i}}{L_{n}}\right] \\
& =\sigma+\left[\sum_{i \in I_{n}}\left(-\frac{\partial \ln \left(L_{i} / L_{n}\right)}{\partial \ln (r / w)}\right) \frac{K_{i}}{K_{n}}\right]
\end{aligned}
$$

Since each firm has an elasticity of substitution of $\sigma$, the within firm component of the elasticity of substitution is $\sigma$. The between firm component depends upon how relative factor prices affect firm labor shares. If each firm keeps the same share of aggregate labor, the aggregate elasticity is equal to the firm level elasticity. The aggregate elasticity of substitution is higher than the firm elasticity $\sigma$ if firms with high capital-labor ratios increase their share of aggregate labor when wages rise.

We thus need to determine how each firm's labor share changes with relative factor prices. Profit maximization implies that firms set factors as follows:

$$
L_{i}=\frac{\lambda_{i}^{\sigma}}{B_{i}^{1-\sigma} w^{\sigma}} Y_{i} \quad K_{i}=\frac{\lambda_{i}^{\sigma}}{A_{i}^{1-\sigma} r^{\sigma}} Y_{i}
$$

where $\lambda_{i}$ is the marginal cost of the firm, which depends upon both factor prices and measures of productivity:

$$
\lambda_{i}=\left[\left(r / A_{i}\right)^{1-\sigma}+\left(w / B_{i}\right)^{1-\sigma}\right]^{\frac{1}{1-\sigma}}
$$


As long as productivity differences across firms are non-neutral, relative factor price changes affect a firm's cost differential relative to the industry. The firm's cost share of capital serves as a sufficient statistic for how relative wage changes affect the firm's marginal cost:

$$
\frac{\partial \ln \left(\lambda_{i} / \lambda_{j}\right)}{\partial \ln (r / w)}=\alpha_{i}-\alpha_{j}
$$

Here $\alpha_{i} \equiv \frac{r K_{i}}{r K_{i}+w L_{i}}$ is the firm's cost share of capital. High capital share firms have a comparative cost advantage relative to the average firm when wages rise.

Profit maximizing firms set price equal to a fixed markup over marginal cost because they face isoelastic demand. Output is a power function of the marginal cost and responds more to marginal cost when demand is more elastic.

$$
\begin{aligned}
P_{i} & =\frac{\epsilon}{\epsilon-1} \lambda_{i} \\
Y_{i} & =D_{i}\left(\frac{\epsilon}{\epsilon-1}\right)^{-\epsilon} \lambda_{i}^{-\epsilon}
\end{aligned}
$$

A firm's share of aggregate labor then becomes:

$$
\frac{L_{i}}{L_{n}}=\frac{\lambda_{i}^{\sigma-\epsilon} B_{i}^{\sigma-1} D_{i}}{\sum_{i} \lambda_{i}^{\sigma-\epsilon} B_{i}^{\sigma-1} D_{i}}
$$

We can then characterize how the relative wage affects the firm's share of aggregate labor by combining the expression for the firm's share of aggregate labor (equation (10)) with the elasticity of the firm's relative marginal cost to the relative wage (equation (7)):

$$
-\frac{\partial \ln \left(L_{i} / L_{n}\right)}{\partial \ln (r / w)}=(\epsilon-\sigma)\left[\alpha_{i}-\sum_{j} \alpha_{j} \frac{L_{j}}{L_{n}}\right]
$$

A higher elasticity of demand allows consumers to substitute more towards low cost firms when factor price changes alter the relative costs of firms. Goods from capital intensive firms become relatively cheaper with an increase in wages, for example, so their share of aggregate labor will rise. Substitution between capital and labor within the firm reduces cost differences across firms from the 
relative price change, so firm shares of aggregate labor shift less when the elasticity of substitution is higher. The total effect is positive if the elasticity of demand is higher than the elasticity of substitution. This condition will be satisfied, for example, if the firm elasticity of substitution is less than one and the elasticity of demand is greater than one.

The between firm component of the industry elasticity of substitution thus depends upon the firm elasticity of substitution, the elasticity of demand for the industry, and the distribution of capital shares across firms. We can then combine equation (11) with equation (4) to produce a simple formulation of the industry elasticity of substitution. Proposition 1 expresses the industry elasticity of substitution as a weighted average of the firm elasticity of substitution and the elasticity of demand:

Proposition 1 Under Assumption 1, an industry composed of firms with identical elasticities of substitution $\sigma$ and demand elasticities $\epsilon$ has an industry elasticity of substitution $\sigma_{n}^{N}=-\frac{\partial \ln \left(K_{n} / L_{n}\right)}{\partial \ln (r / w)}$ :

$$
\begin{aligned}
\sigma_{n}^{N} & =(1-\chi) \sigma+\chi \epsilon \\
\chi & \equiv \sum_{i \in I_{n}} \frac{\left(\alpha_{i}-\alpha_{n}\right)^{2}}{\left(1-\alpha_{n}\right) \alpha_{n}} \frac{c_{i}}{c_{n}}
\end{aligned}
$$

Here, $c_{i} \equiv \lambda_{i} Y_{i}$ is the total cost of production for firm $i$, with $c_{n}=\sum_{i \in I_{n}} c_{i}$. Also, $\alpha_{n} \equiv$ $\frac{r K_{n}}{r K_{n}+w L_{n}}$ is the capital share of cost for the industry. The proofs of all propositions are contained in Appendix A.

Both the firm elasticity of substitution and the elasticity of demand increase factor substitution. When relative factor prices change, firm differences in capital cost shares from equation (7) determine how relative marginal costs shift. The cost weighted variance of capital shares is a sufficient statistic that expresses how much these cost share differences increase the industry elasticity of substitution.

The weight $\chi$ is the cost weighted variance of capital shares normalized by the industry cost share of capital and cost share of labor. This weight ranges from zero to one. ${ }^{11}$ When cost shares of capital are the same for every plant within the industry, so that all productivity differences are

\footnotetext{
${ }^{11} \mathrm{~A}$ simple proof: $\sum_{i \in I_{n}}\left(\alpha_{i}-\alpha_{n}\right)^{2} \frac{c_{i}}{c_{n}}=\sum_{i \in I_{n}} \alpha_{i}^{2} \frac{c_{i}}{c_{n}}-\alpha_{n}^{2} \leq \sum_{i \in I_{n}} \alpha_{i} \frac{c_{i}}{c_{n}}-\alpha_{n}^{2}=\alpha_{n}-\alpha_{n}^{2}=\alpha_{n}\left(1-\alpha_{n}\right)$. It follows that $\chi=1$ if and only if each firm uses only capital or only labor (i.e., for each $i, \alpha_{i} \in\{0,1\}$ ).
} 
neutral, the weight is zero and the industry elasticity of substitution is just the plant level elasticity of substitution. The industry elasticity of substitution is equal to the elasticity of demand if the weight is one. In this case, firms use either capital only or labor only technologies, so all substitution in factors is across firms. Thus, we can characterize the industry elasticity of substitution as a function of only three parameters: the firm elasticity of substitution, elasticity of demand, and the normalized cost weighted variance of capital shares!

We can easily modify the formulas above to allow firms to have heterogenous constant returns to scale production functions. In this case, each firm's elasticity of substitution is defined locally, and the elasticity of a firm's share of aggregate labor depends upon all elasticities of substitution:

$$
\begin{aligned}
-\frac{d \ln \left(K_{i} / L_{i}\right)}{d \ln (r / w)} & =\sigma_{i} \\
-\frac{d \ln \left(L_{i} / L_{n}\right)}{d \ln (r / w)} & =\left[\left(\epsilon-\sigma_{i}\right) \alpha_{i}-\sum_{j}\left(\epsilon-\sigma_{j}\right) \alpha_{j} \frac{L_{j}}{L_{n}}\right]
\end{aligned}
$$

Proposition 2 expresses the industry elasticity of substitution $\sigma_{n}^{N}$ :

Proposition 2 Under Assumption 1, an industry composed of firms with local elasticities of substitution $\sigma_{i}$ and demand elasticities $\epsilon$ has an industry elasticity of substitution $\sigma_{n}^{N}=-\frac{\partial \ln \left(K_{n} / L_{n}\right)}{\partial \ln (r / w)}$ :

$$
\begin{aligned}
\sigma_{n}^{N} & =(1-\chi) \bar{\sigma}_{n}+\chi \epsilon \\
\chi & \equiv \sum_{i \in I_{n}} \frac{\left(\alpha_{i}-\alpha_{n}\right)^{2}}{\left(1-\alpha_{n}\right) \alpha_{n}} \frac{c_{i}}{c_{n}} \\
\bar{\sigma}_{n} & \equiv \frac{\sum_{i \in I_{n}} c_{i} \alpha_{i}\left(1-\alpha_{i}\right) \sigma_{i}}{\sum_{i \in I_{n}} c_{i} \alpha_{i}\left(1-\alpha_{i}\right)}
\end{aligned}
$$

In relation to equation (12), we simply replace the firm elasticity of substitution with a weighted average of the firms' elasticities $\bar{\sigma}_{n}$, weighting firms by the firm's share of total industry cost multiplied by the capital share of cost and labor share of cost. Thus large firms are weighted more while firms with extreme capital shares are weighted less in the weighted firm elasticity of substitution. 


\section{$2.2 \quad$ Aggregating across Industries}

So far, we have shown how to aggregate from the firm level to the industry level. Can we then aggregate further, to the the entire manufacturing sector? We can so long as demand has a nested structure, with a constant elasticity at each level of aggregation. Such a structure is consistent with a representative customer whose preferences exhibit constant elasticities of substitution within an industry and across industries:

$$
\left(\sum_{n \in N} \tilde{D}_{n}\left(\sum_{i \in I_{n}} \tilde{D}_{i}^{\frac{1}{\epsilon_{n}}} Y_{i}^{\frac{\epsilon_{n}-1}{\epsilon_{n}}}\right)^{\frac{\epsilon_{n}}{\epsilon_{n}-1} \frac{\eta-1}{\eta}}\right)^{\frac{\eta}{\eta-1}}
$$

The innermost sum is over all producers $i$ in $I_{n}$, the set of firms in industry $n$, while the outer sum is over all industries $n$ in $N$, the set of all industries. In this setup, $\epsilon_{n}$ is the elasticity of demand within industry $n$ while $\eta$ is a parameter that indexes substitution across industries. A firm's demand depends upon both its own price relative to its competitors, the industry price index relative to the other industries, and aggregate demand:

$$
Y_{i}=Y\left(\frac{P_{n}}{P}\right)^{-\eta}\left(\frac{P_{i}}{P_{n}}\right)^{-\epsilon_{n}}
$$

Our aggregation analysis is the same at the industry level, as each of the firms in the industry faces isoelastic demand as in equation (2). Thus, the elasticity of substitution for industry $n$ as a whole is:

$$
\begin{aligned}
\sigma_{n}^{N} & =\left(1-\chi_{n}\right) \sigma_{n}+\chi_{n} \epsilon_{n} \\
\chi_{n} & =\sum_{i \in I_{n}} \frac{c_{i}}{c_{n}} \frac{\left(\alpha_{i}-\alpha_{n}\right)^{2}}{\left(1-\alpha_{n}\right) \alpha_{n}}
\end{aligned}
$$

Here, $\sigma_{n}$ is the firm level elasticity of substitution for industry $n, \sigma_{n}^{N}$ is the elasticity of substitution between capital and labor for industry $n$ as a whole, $-\frac{d \ln K_{n} / L_{n}}{d \ln r / w}$, and $\alpha_{n}$ is the industry cost share of capital. We compute the aggregate elasticity of substitution in a parallel way. Each 
industry has a local industry elasticity of substitution $\sigma_{n}^{N}$ and elasticity of demand $\eta$ :

$$
Y_{n}=Y\left(\frac{P_{n}}{P}\right)^{-\eta}
$$

Proposition 3 shows that the aggregate elasticity of substitution is a convex combination of the elasticity of demand $\eta$ that the industry faces and a weighted average $\bar{\sigma}^{N}$ over the industry elasticities of substitution.

Proposition 3 Under Assumption 1 and nested CES demand, the aggregate elasticity of substitution $\sigma^{a g g}=-\frac{d \ln (K / L)}{d \ln (r / w)}$ is:

$$
\begin{aligned}
\sigma^{a g g} & =\left(1-\chi^{a g g}\right) \bar{\sigma}^{N}+\chi^{a g g} \eta \\
\bar{\sigma}^{N} & =\frac{\sum_{n \in N} c_{n} \alpha_{n}\left(1-\alpha_{n}\right) \sigma_{n}}{\sum_{n \in N} c_{n} \alpha_{n}\left(1-\alpha_{n}\right)} \\
\chi^{a g g} & =\sum_{n \in N} \frac{c_{n}}{c} \frac{\left(\alpha_{n}-\alpha\right)^{2}}{\alpha(1-\alpha)}
\end{aligned}
$$

where $\left\{\sigma_{n}^{N}\right\}_{n \in N}$ are the industry elasticities of substitution defined in Proposition 2.

The weight between these two parameters depends on the cost weighted variance in capital cost shares across industries. This variance in capital shares of cost captures the difference between capital intense and labor intense industries rather than between firms with different levels of productivity. As long as demand has a nested CES structure, we can use these formulas to form the elasticity of substitution at any level of aggregation!

\subsection{Materials}

So far, we have assumed that each firm's production function has only capital and labor as inputs. In this section, we extend our results to allow additional factors of production such as materials. We assume a gross output production function that is Cobb-Douglas between materials $M_{i}$ and a 
CES capital-labor aggregate:

$$
\begin{aligned}
Y_{i} & =M_{i}^{\gamma} F_{i}\left(K_{i}, L_{i}\right)^{1-\gamma} \\
F_{i}(K, L) & =\left[\left(A_{i} K\right)^{\frac{\sigma-1}{\sigma}}+\left(B_{i} L\right)^{\frac{\sigma-1}{\sigma}}\right]^{\frac{\sigma}{\sigma-1}}
\end{aligned}
$$

The key assumptions that we need for tractability are that gross output is a Cobb-Douglas aggregate of materials and the capital labor aggregate and that each firm faces the same cost index for materials. ${ }^{12}$ Separability ensures that the firm's elasticity of substitution between capital and labor is $\sigma$ and does not depend upon the price of materials. Each firm maximizes profit given isoelastic demand and perfectly competitive input markets for all inputs, with factor prices $r$ for capital, $w$ for labor, and $p_{m}$ for materials. Cost minimization implies that the elasticity of output to materials $\gamma$ is also the materials share of total cost.

To determine the industry elasticity of substitution, we have to characterize how the firm's share of aggregate labor changes with relative factor prices of capital and labor. The firm's share of aggregate labor is more sensitive to the relative wage when $\gamma$ is low, as materials are a small share of total cost. The marginal cost of the firm is now:

$$
g(\gamma) \lambda_{i}^{1-\gamma} p_{m}^{\gamma}
$$

where, as before, $\lambda_{i}=\left[\left(r / A_{i}\right)^{1-\sigma}+\left(w / B_{i}\right)^{1-\sigma}\right]^{\frac{1}{1-\sigma}}$ is the marginal cost of the capital-labor aggregate and $g(\gamma) \equiv \gamma^{-\gamma}(1-\gamma)^{-(1-\gamma)}$.

The marginal cost of the firm is proportional to the weighted geometric average of the marginal cost of the capital-labor aggregate $\lambda_{i}$ and the marginal cost of materials $p_{m}$, in which the weight is the output-materials elasticity $\gamma$. The firm's marginal cost only depends upon relative factor prices of capital and labor through the marginal cost of the capital-labor aggregate $\lambda_{i}$. Thus, the firm's

\footnotetext{
${ }^{12}$ Since materials are composed of the goods of other firms, changes in the prices of labor and capital would undoubtedly affect the price of materials. These assumptions guarantee that any change in the price of materials has the same impact on each firm's marginal cost. As a consequence, changes in $r / w$ have no extra indirect effect on the substitution across firms through the cost of materials.

We could avoid the first assumption through an alternative assumption about how changes in $r / w$ impact the price of materials. The second assumption is much harder to work around, as it would require data on which plants use materials that were produced using more capital intensive technologies.
} 
cost is less sensitive to such relative factor price changes when $\gamma$ is larger, as the prices of capital and labor matter less when those inputs are a smaller share of total cost.

Profit maximization implies that the firm's level of labor is:

$$
L_{i}=\frac{\lambda_{i}^{\sigma}}{w^{\sigma} B_{i}^{1-\sigma}} F_{i}\left(K_{i}, L_{i}\right)
$$

We can then solve for the optimal level of materials for the firm, and then use both the optimized materials and the implications of isoelastic demand to determine the capital-labor aggregate:

$$
F_{i}\left(K_{i}, L_{i}\right)=D_{i} h\left(p_{m}, \gamma, \epsilon\right) \lambda_{i}^{-[\epsilon(1-\gamma)+\gamma]}
$$

This equation is analogous to equation (9) from the case with only capital and labor as factor inputs. However, the level of the capital-labor aggregate is now less elastic to changes to its own marginal cost. A higher materials share $\gamma$ is thus isomorphic in the model to a lower elasticity of demand after the elasticity of demand $\epsilon$ is replaced by a convex combination between $\epsilon$ and 1 with a weight of $\gamma$. The labor share of aggregate labor is then less elastic to changes in relative factor prices:

$$
-\frac{\partial \ln \left(L_{i} / L_{n}\right)}{\partial \ln (r / w)}=([\epsilon(1-\gamma)+\gamma]-\sigma)\left[\alpha_{i}-\sum_{j \in I_{n}} \alpha_{j} \frac{L_{j}}{L_{n}}\right]
$$

Here, $\alpha_{i}$ is the firm's capital share of non materials cost. As $\gamma$ increases, the firm share of aggregate labor responds less to changes in the relative price of capital to labor $r / w$. Proposition 4 expresses the industry elasticity of substitution when the production function includes materials:

Proposition 4 Under Assumption 1, an industry composed of firms with identical elasticities of substitution $\sigma$ and demand elasticities $\epsilon$ and materials share $\gamma$ has an industry elasticity of substi- 
tution $-\frac{\partial \ln \left(K_{n} / L_{n}\right)}{\partial \ln (r / w)}$ :

$$
\begin{aligned}
-\frac{\partial \ln \left(K_{n} / L_{n}\right)}{\partial \ln (r / w)} & =(1-\chi) \sigma+\chi[\epsilon(1-\gamma)+\gamma] \\
\chi & =\sum_{i \in I_{n}} \frac{\left(\alpha_{i}-\alpha_{n}\right)^{2}}{\left(1-\alpha_{n}\right) \alpha_{n}} \frac{c_{i}}{c_{n}}
\end{aligned}
$$

Here, $\alpha_{n}$ is the capital share of non-materials cost for the industry as a whole, while $c_{i}$ and $c_{n}$ are the total non-materials cost for firm $i$ and industry $n$ as a whole. A higher share of materials in the production function lowers the industry elasticity of substitution, as it reduces the impact of changes in primary factor prices on firms' marginal costs.

In our estimation, we assume that all firms in industry $n$ have a materials share $\gamma_{n}$. When we estimate the aggregate elasticity of substitution for the manufacturing sector, we also assume that the cross-industry elasticity of substitution $\eta$ is equal to 1 . In this case, the representative consumer's expenditure share on any industry does not respond to the price index for that industry. Changes in the wage or rental rate of capital do not affect the relative scale of each industry even if the price of materials depends upon these factor prices. In this way, we sidestep having to estimate how the price of materials responds to other factor prices.

\subsection{The Bias of Technical Change}

A firm's capital-labor ratio depends on relative factor prices and on productivity through the ratio of labor augmenting productivity to capital augmenting productivity $\frac{B_{i}}{A_{i}}$ :

$$
d \ln \frac{r K_{i}}{w L_{i}}=(1-\sigma) d \ln \frac{r}{w}+(1-\sigma) d \ln \frac{B_{i}}{A_{i}}
$$

$\phi_{i} \equiv(1-\sigma) d \ln \left(\frac{B_{i}}{A_{i}}\right)$ is the bias in technical change for the firm. If $\frac{B_{i}}{A_{i}}$ increases over time then technical growth is, on net, labor augmenting, while if $\frac{B_{i}}{A_{i}}$ falls over time then technical growth is, on net, capital augmenting. The effect of technical change on the capital-labor ratio depends upon the elasticity of substitution as well. Technical change is capital biased (so $\frac{K}{L}$ increases) with either labor augmenting technical growth and an elasticity of substitution less than one, or with capital 
augmenting technical growth and an elasticity greater than one.

We can assess the bias of technical change for an industry as a whole in the same manner. The previous subsections have shown how changes in relative factor prices affect the aggregate capitallabor ratio. Biased movements in aggregate productivity also affect the aggregate capital-labor ratio. We can measure the bias in technical change as a residual, after accounting for the effects of factor prices:

$$
\phi_{n}^{N}=d \ln \frac{r K_{n}}{w L_{n}}+\left(\sigma_{n}^{N}-1\right) d \ln \frac{r}{w}
$$

The bias in aggregate technical change depends on upon both changes in productivity within firms and changes in market shares across firms in the industry. Let $T$ denote technology and preferences at a point in time. We capture these two effects in equation (28):

$$
\begin{aligned}
\phi_{n}^{N} & =\frac{\partial \ln \left(K_{n} / L_{n}\right)}{\partial T} d T \\
& =\sum_{i \in I_{n}} \frac{\partial \ln \left(K_{i} / L_{i}\right)}{\partial T} d T \frac{K_{i}}{K_{n}}+\sum_{i \in I_{n}} \frac{\partial \ln \left(L_{i} / L_{n}\right)}{\partial T} d T \frac{K_{i}}{K_{n}}
\end{aligned}
$$

The direction of aggregate technical change can shift through biased technical change within plants, or through shifts in the relative shares of firms that use different technologies. For example, labor augmenting growth at the aggregate level could come solely from growth in firms that use labor augmenting technologies, without any change in the direction of technology at the firm level. We can decompose the bias in technical change into the contribution of biased technical change within firms and the contribution of changes in firm market shares. The following proposition contains this decomposition:

Proposition 5 Consider an industry composed of firms that produce with CES production functions with elasticity of substitution $\sigma$. Under Assumption 1, the bias of technical change for the industry as a whole can be decomposed as:

$$
\begin{aligned}
\phi_{n}^{N} & =(1-\chi) \bar{\phi}_{n}+\sum_{i \in I_{n}} \frac{\alpha_{i}-\alpha_{n}}{\alpha_{n}\left(1-\alpha_{n}\right)} \frac{c_{i}}{c_{n}} g_{i} \\
\bar{\phi}_{n} & \equiv \frac{\sum_{i \in I_{n}} c_{i} \alpha_{i}\left(1-\alpha_{i}\right) \phi_{i}}{\sum_{i \in I_{n}} c_{i} \alpha_{i}\left(1-\alpha_{i}\right)}
\end{aligned}
$$


where $\chi$ is the weight defined in equation (1) and $g_{i} \equiv d \ln D_{i}+(\epsilon-1)\left[\alpha_{i} d \ln A_{i}+\left(1-\alpha_{i}\right) d \ln B_{i}\right]$ is the change in scale of firm $i$ due to changes in technology and preferences.

The within firm contribution to the bias of technical change is $(1-\chi) \bar{\phi}_{n}$, as $\bar{\phi}_{n}$ is a weighted average of the bias of productivity growth for every firm. Firms that are a larger share of industry cost or have a less extreme capital share of cost have a larger impact on the bias of aggregate productivity.

The between firm contribution to the bias of technical growth $\sum_{i \in I_{n}} \frac{\alpha_{i}-\alpha_{n}}{\alpha_{n}\left(1-\alpha_{n}\right)} \frac{c_{i}}{c_{n}} g_{i}$ is the weighted covariance between the firms' capital shares of cost $\alpha_{i}$ and the changes in firms' scales $g_{i}$. A firm's scale could rise either because its marginal cost falls relative to the industry through productivity improvements, or because the firm's demand rises relative to average demand in the industry. For example, the realignment of industry shares induced by high capital share firms becoming a larger share of the industry leads to labor augmenting technical growth at the aggregate level.

We can construct similar indices for changes in aggregate technology as well, using the setup of Section 2.2. In this case, we can decompose the bias of aggregate technical change into a within firm contribution, a between firm but within industry contribution, and a between industry contribution. Here, $g_{n} \equiv \sum_{i \in I_{n}} \frac{c_{i}}{c_{n}} g_{i}$ is a weighted average for the industry of each firm's change in marginal cost.

Proposition 6 The bias of aggregate technical change $\phi^{a g g}$ can be decomposed as:

$$
\begin{aligned}
\phi^{a g g} & =\left(1-\chi^{a g g}\right) \bar{\phi}^{N}+\sum_{n \in N} \frac{\alpha_{n}-\alpha}{\alpha(1-\alpha)} \frac{c_{n}}{c} g_{n} \\
\bar{\phi}^{N} & \equiv \frac{\sum_{n \in N} c_{n} \alpha_{n}\left(1-\alpha_{n}\right) \phi_{n}^{N}}{\sum_{n \in N} c_{n} \alpha_{n}\left(1-\alpha_{n}\right)}
\end{aligned}
$$

where $\chi^{\text {agg }}$ is as defined in equation (3).

The within firm and between firm within industry terms are similar to those in equation (6). However, each term is now a weighted sum across industries in which the weights depend upon each industry's share of total cost and capital share of cost. The new, between industry term is a weighted covariance between the change of the industry's share of total aggregate cost $g_{n}$ and the 
industry's capital share relative to the aggregate capital share of cost $\alpha_{n}-\alpha$. If preferences are Cobb-Douglas across industries, then this term disappears because industry shares of total cost are constant. Otherwise, the between industry term affects the bias of aggregate productivity when shifts in sectoral composition are correlated with the industry capital share of cost. For example, if technical change causes the share of capital intensive heavy manufacturing in total manufacturing to shrink, this component of aggregate technical change would be labor biased.

\section{Estimation}

In this section, we apply the formulas developed in Section 2 together with rich microdata on US manufacturing plants to examine the intensive margin of the aggregate elasticity of substitution. Section 3.1 covers the US micro data that we use in this paper.

To obtain the macro elasticity of substitution, we have to separately estimate three components: the plant level elasticity of substitution, the elasticity of demand, and the normalized variance of capital shares. Section 3.2, Section 3.3, and Section 3.4 detail how we estimate each one of these components. Section 3.5 combines all of these to produce estimates of the elasticity of substitution at the industry and sector level.

Section 3.6 examines the robustness of our estimates to how we model and estimate customer demand. Lastly, we use our estimates of the aggregate elasticity of substitution to assess the source of the aggregate bias of technical change in Section 3.7.

\subsection{Data}

Our data source for microdata on manufacturing plants is the US Census of Manufactures. The Census of Manufactures is a census of all manufacturing plants that the US Census undertakes every five years. Each Census sample has more than 180,000 plants and considerable variation within ages, geographic areas, and industries. Currently, we use the 1987 and 1997 Census of Manufactures, because the Census asked all plants to record capital data in these years. ${ }^{13}$

\footnotetext{
${ }^{13}$ We exclude small Administrative Record plants with less than five employees, for whom the Census only tracks payroll and employment. This omission is in line with the rest of the literature using manufacturing Census data.
} 
To form firm capital shares, we use capital costs and labor costs measured at the plant level. Labor costs are the total salaries and wages at the plant level. We measure capital by the end year book value of capital, deflated using a current cost to historic cost deflator. The 1987 Census has book values for equipment capital and structures capital separately, so we construct capital stocks for each and then combine them. For capital costs, we multiply these measures of capital stocks by the appropriate rental rate.

Currently, we measure the capital rental rate as the overall capital income to capital stock ratio for all of manufacturing, which is $13.5 \%$ for equipment capital and $11 \%$ for structures capital. We have examined robustness to this assumption by using a set of unpublished BLS rental rates calculated by capital income to capital stock measures across two digit SIC industries, and found similar results. We are currently working on constructing a consistent series of the capital rental rate across time and industry.

We also use data on a set of homogenous products for which the Census has collected both physical quantity and revenue data. We define these products using the definitions in Foster et al. (2008), and apply the same filters on the data as they do, including a $50 \%$ product specialization cutoff that only includes plants that derive at least $50 \%$ of their revenue from the given product. For concrete, we can only use data from 1987 and 1992 as no physical quantity data was recorded for 1997. For processed ice, recording errors invalidate data from 1992. For boxes, physical quantity measures changed between 1987 and 1992 that make it impossible to compare the post 1992 data to the rest of the data. We only use data from 1992 and 1997, unlike Foster et al. (2008) who use data from 1987 and earlier.

\subsection{The Elasticity of Substitution at the Micro Level}

For the micro elasticity of substitution, we use Raval (2011)'s estimates from cross-sections of US manufacturing plants. Raval (2011) assumes that manufacturing plants cost minimize using a CES production function. Cost minimization implies that the slope of the relationship between the log factor price ratio and log factor cost ratio identifies the elasticity of substitution, as the following equation demonstrates: 


$$
\log (r K / w L)=-(1-\sigma) \log (w / r)+(1-\sigma) \log (B / A)+\sigma \log \frac{\alpha}{1-\alpha}
$$

For factor price variation, Raval (2011) exploits wage differences across local areas in the US for identification. Because the variation in wages across local areas is strongly persistent over time, this method will identify the long run elasticity of substitution between capital and labor. Raval (2011) uses the Census 5\% sample of Americans as the primary source of wages, so that local area wage measures control for individual differences in education, occupation, and experience. ${ }^{14}$ Industry fixed effects control for cross industry differences in capital intensity. Plants in areas with high wages have a lower cost share of capital, just as on would expect when the plant level elasticity is less than one.

Raval (2011) finds a plant level elasticity of substitution close to $1 / 2$ for overall manufacturing in both 1987 and 1997. For our analysis we use his estimates for the 2 digit SIC level. Figure 1 displays these estimates: almost all of them are less than one and most range between .4 and .7. We report all of these estimates in Appendix B. Raval (2011) contains a battery of robustness checks on these elasticities, which include adding firm fixed effects, instrumenting wages, and using alternative measures of capital.

\subsection{The Elasticity of Demand}

We next compute the elasticity of demand for each industry. Our model assumes that customers substitute across firms within industry $n$ with elasticity $\epsilon_{n}$, and across industries within the manufacturing sector with elasticity $\eta$. When going to the data, we must take a stand on the right level of aggregation for an industry. In our baseline estimation, we assume industries in the model correspond to 2 digit SIC industries. We examine the sensitivity of our estimates to this assumption in Section 3.6.1.

We then derive the elasticity of demand from the price cost margin through assumptions of profit maximization and a constant elasticity of demand. ${ }^{15}$ Optimal price setting behavior implies

\footnotetext{
${ }^{14}$ The Census Longitudinal Business Database provides an alternative source of establishment based county level wages, though these can not control for individual differences that would affect wages.

${ }^{15}$ In Section 3.6.2, we use the alternative approach of estimating demand functions using supply side instruments
} 
Figure 1 Plant Elasticity of Substitution by 2 Digit Industry, 1987

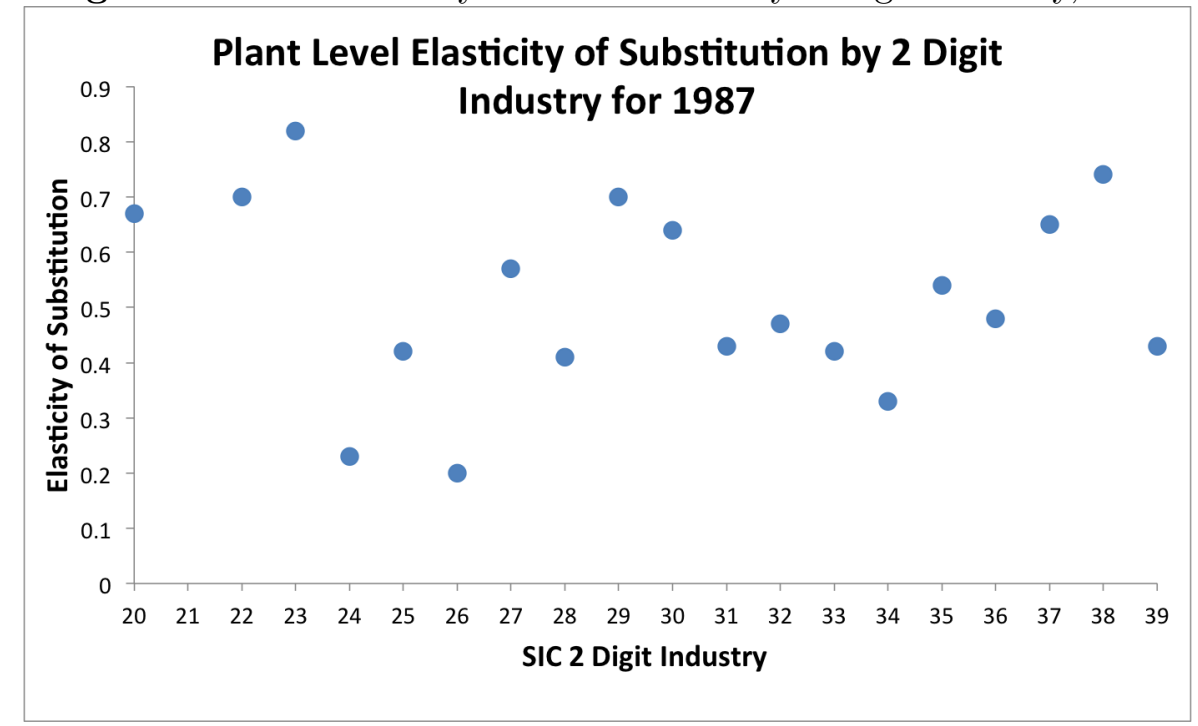

For each SIC 2 digit industry, this graph plots the plant level elasticity of substitution between capital and labor as estimated in Raval (2011).

that the markup over marginal cost is equal to $\frac{\varepsilon}{\varepsilon-1}$, so we can invert the markup to obtain the elasticity of demand. The ratio of revenue to total cost identifies the markup under constant returns to scale. We invert the average markup across plants in an industry to obtain the elasticity of demand. Figure 2 displays estimates for 1987 for each 2 digit industry. All of these demand elasticities range between three and five; Appendix C contains the elasticity of demand for each 2 digit industry for 1987 and 1997.

When production uses materials, the formula for the industry elasticity of substitution uses a weighted average of the elasticity of gross demand and $1, \epsilon_{n}\left(1-\gamma_{n}\right)+\gamma_{n}$, where $\gamma_{n}$ is the materials share of cost for industry $n$. Materials shares are high, with an average of .696 for the entire manufacturing sector in 1987. Naturally, a higher materials share lowers this weighted average, and hence the industry elasticity of substitution. Appendix D contains the materials shares for each 2 digit industry. Figure 2 shows the elasticity of demand along with the weighted average $\epsilon_{n}\left(1-\gamma_{n}\right)+\gamma_{n}$ across all of the 2 digit industries in 1987. While the elasticity of demand tends to for a selected set of industries that have product level price data. For most industries, however, such product level prices are unavailable. 
vary between 3-5 at the industry level, the weighted average after accounting for materials is close to 2 for most industries and to 1.5 for industries with high materials shares.

Figure 2 Elasticity of Demand and Materials by 2 Digit Industry, 1987

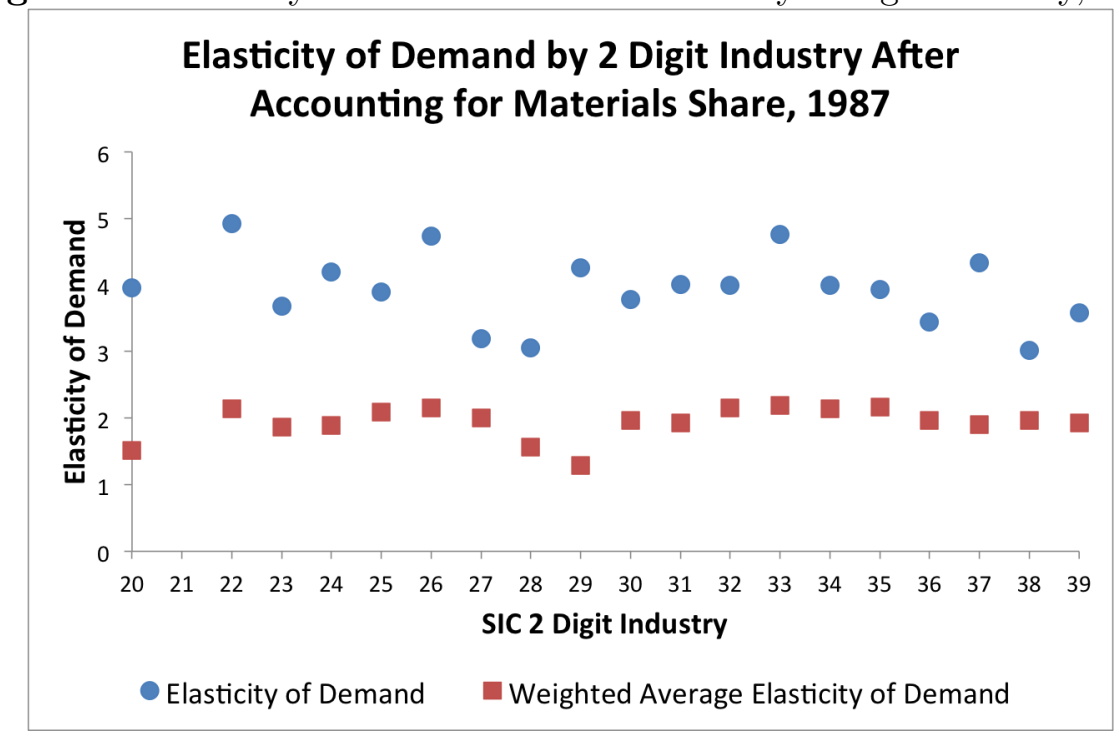

For each SIC 2 digit industry, this graph plots both the elasticity of demand estimated from the revenue to total cost ratio, and the weighted average of 1 and the elasticity of demand, weighted by the materials share of cost.

\subsection{Normalized Variance of Capital Shares}

We now compute the normalized variance of the capital shares of cost, which is the cost weighted variance of capital shares within a industry rescaled to lie between zero and one. This weight determines the relative importance of substitution within plants over substitution between plants. The normalized variance of factor shares is

$$
\chi \equiv \sum_{i \in I_{n}} \frac{\left(\alpha_{i}-\alpha_{n}\right)^{2}}{\left(1-\alpha_{n}\right) \alpha_{n}} \frac{c_{i}}{c_{n}}
$$

where $\alpha_{i}$ is the cost share of capital for firm $i, \alpha_{n}$ is the cost share of capital for industry $n, c_{i}$ is firm $i$ 's total cost, and $c_{n}$ the industry's total cost.

Figure 3 displays each of these weights for each 2 digit industry in 1987. While there is some 
variation in capital shares, plants have sufficiently similar factor intensities that the dominant channel of substitution is within plants. Because of this, the plant level elasticity of substitution will be much more important than the elasticity of demand in determining the industry level elasticity of substitution. All of the weights are below .2, which implies that substitution within plants will dominate substitution across plants. Appendix E contains all of these capital share weights.

Figure 3 Normalized Variance of Capital Shares by 2 Digit Industry, 1987

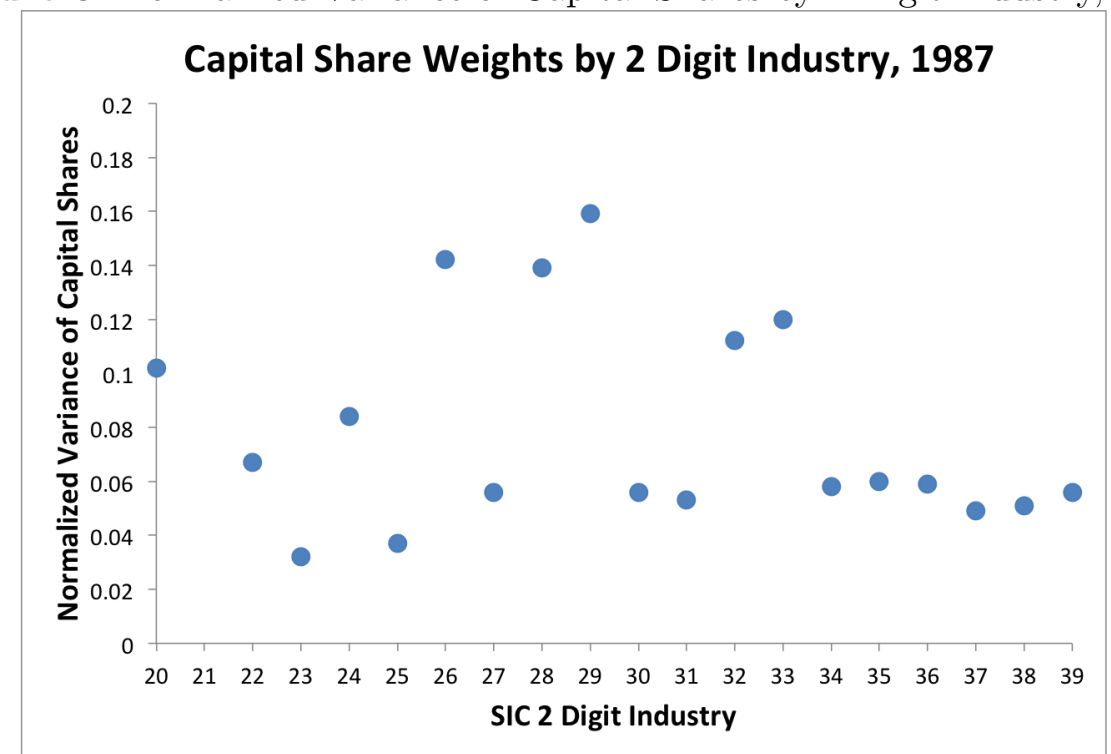

For each SIC industry, this graph displays the normalized variance of capital shares, $\chi_{n}$ assuming that the SIC 2 digit industries are the relevant level of aggregation.

\subsection{Aggregate Elasticities of Substitution}

We can now compute the elasticity of substitution at higher levels of aggregation. Figure 6 displays the plant level and industry level elasticities of substitution. For all industries, the industry level elasticity of substitution is only moderately higher than the plant level elasticity. If we weigh each industry elasticity by the weight from equation (22) based upon its share of total manufacturing cost and capital share, the average industry elasticity is .652, $21.8 \%$ higher than the average plant elasticity. 
Figure 4 Elasticity of Substitution by 2 Digit Industry, 1987

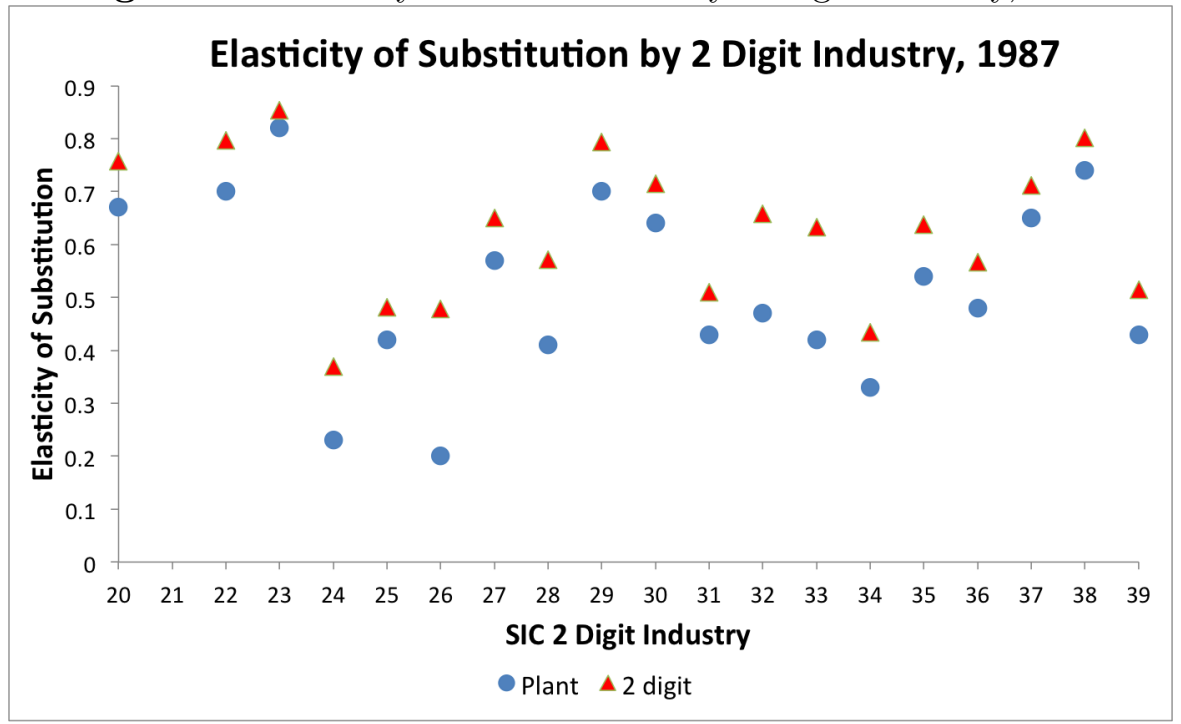

The plant level elasticity is the elasticity of substitution for 1987 for the 2 digit industry reported in Table III. The 2 digit elasticity of substitution computes the industry elasticity of substitution assuming that the relevant industries are at the 2 digit level.

We can now use equation (21) to characterize the overall manufacturing elasticity of substitution. We assume as before that the cross industry elasticity of substitution $\eta$ is 1 . A cross-industry normalized variance of capital shares of .09 implies that the overall manufacturing level elasticity of substitution of .683. Thus, the overall manufacturing sector elasticity is $27.8 \%$ higher than the average plant-level elasticity of substitution.

We also examine the stability of the aggregate elasticity of substitution by performing the same exercise for 1997. We use 1997 estimates of the plant level elasticity of substitution, elasticity of demand, normalized variance of capital shares, and materials share to form an overall manufacturing level elasticity of substitution. Using this approach, the 1997 manufacturing level elasticity is .717, slightly higher than the 1987 manufacturing-level elasticity. Thus, our estimates indicate that the overall manufacturing elasticity rose slightly within a ten year time span.

Of course, many moving parts are changing at once when we go from 1987 to 1997 in this analysis. Table I below breaks down the estimates as we change each the component parts from the 1987 value to the 1997 value. The 1997 estimates of the plant level elasticity of substitution 
slightly increase the overall manufacturing estimate, while the 1997 values of the demand elasticities and materials shares slightly decrease it. Together, the change in these values barely affects the estimates.

The main difference between the 1987 and 1997 estimates of the aggregate elasticity of substitution comes from changes in the composition of plants. The normalized variance of capital shares is higher on average in 1997 than in 1987, which raises the manufacturing elasticity estimates. If we just change the 1987 capital share variance to the 1997 capital share variance, we increase the manufacturing level elasticity from .683 to .714, close to the overall 1997 value of .717.

Table I Stability of Manufacturing Level Elasticity of Substitution from 1987 to 1997

\begin{tabular}{ccccc}
\hline & $\begin{array}{c}1987 \\
\text { Values }\end{array}$ & $\begin{array}{c}1997 \\
\text { Values }\end{array}$ & Parameter Changed to 1997 Value \\
\hline $\begin{array}{c}\text { Plant Level Elasticity of } \\
\text { Substitution }\end{array}$ & & & $\mathrm{Y}$ & $\mathrm{N}$ \\
\cline { 1 - 1 } $\begin{array}{c}\text { Elasticity of Demand and } \\
\text { Materials Share }\end{array}$ & & $\mathrm{Y}$ & $\mathrm{N}$ \\
\cline { 3 - 5 } $\begin{array}{c}\text { Normalized Variance of } \\
\text { Capital Shares }\end{array}$ & & 0.714 & 0.685 & 0.717 \\
\hline $\begin{array}{c}\text { Manufacturing Level } \\
\text { Elasticity of Substitution }\end{array}$ & 0.683 & & $\mathrm{~N}$ & $\mathrm{Y}$ \\
\hline
\end{tabular}

Note: This table records the manufacturing level elasticity of substitution as all of the components of the manufacturing level elasticity of substitution are changed from their 1987 value to their 1997 value.

\subsection{Alternative Specifications}

\subsubsection{Alternative Industry Definition}

In our baseline estimation, we assume that industries in the model correspond to 2 digit SIC industries. We now examine the sensitivity of our estimates to different assumptions on customer substitution through the alternative assumption that industries correspond to 4 digit SIC indus- 
tries. $^{16}$

For this exercise, we will use our estimates of the plant level elasticity of substitution, elasticity of demand, and materials share for the corresponding 2 digit SIC industry.

We first compute the normalized variances of capital share within each industry. These are shown in Figure 5. The figure shows this normalized variance under each of the assumptions that 2 digit (red triangle) and 4 digit (green square) industries are the relevant level of aggregation. The normalized variance within a 2 digit industry is higher than the average normalized variance within its 4 digit sub-industries. All of the weights are below .2, which implies that substitution within plants will dominate substitution across plants. Appendix E contains all of these capital share weights.

Figure 5 Normalized Variance of Capital Shares by 2 Digit Industry, 1987

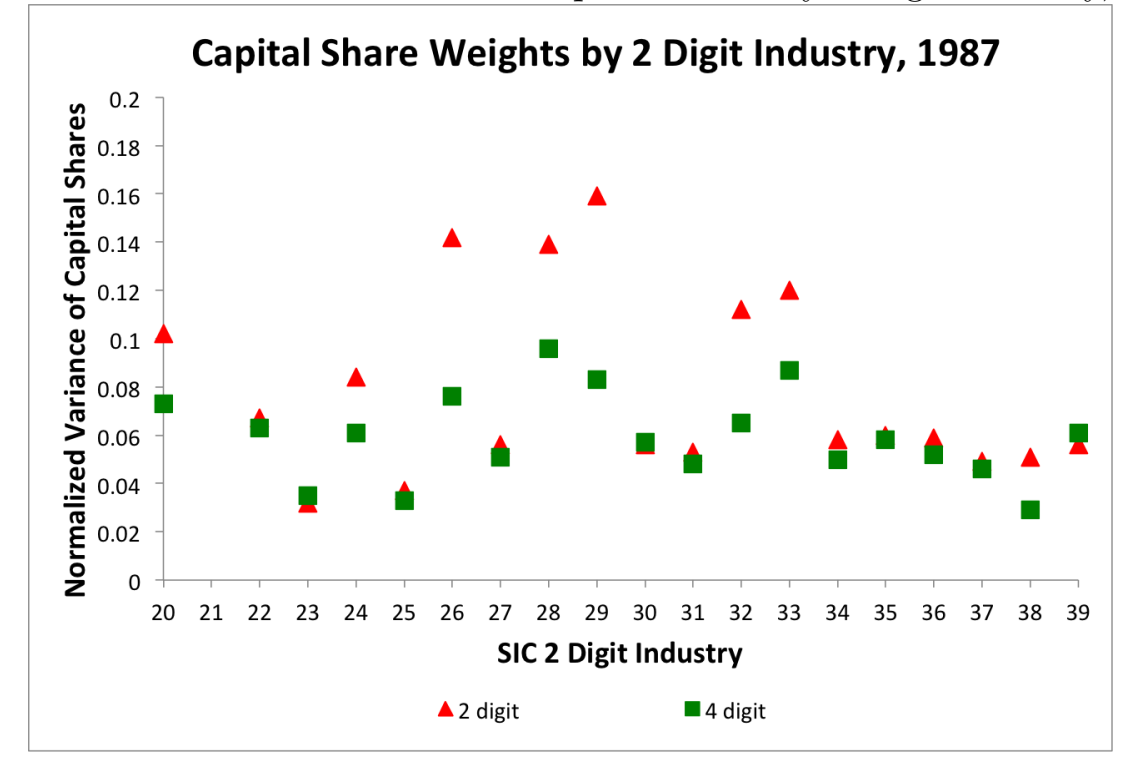

For each SIC industry, this graph displays the normalized variance of capital shares, $\chi_{n}$. The red triangle is the normalized variance of capital shares assuming SIC 2 digit industries are the relevant level of aggregation. The green square assumes that SIC 4 digit industries are the relevant unit of aggregation; the number reported is the average across each 4 digit industries within a 2 digit industry.

\footnotetext{
16 The appropriateness of either of these assumptions depends upon the industries in question. For some 2 digit industries, output from different 4 digit subindustries is quite substitutable. A good example is sugar: Beet Sugar (SIC 2063) produces the same output as Cane Sugar Refining (SIC 2062) within Food Products. For other 2 digit industries, we do not think that plants compete with each other directly. For example, three very disparate industries, Motor Vehicles (SIC 3711), Tanks (SIC 3795), and Aircraft (SIC 3721), are all contained within Transportation Equipment.
} 
We next compute the elasticity of substitution between capital and labor at the industry level. Figure 6 displays the plant level elasticity of substitution and along with two different measures of the elasticity of substitution for each 2 digit industry for 1987. The red triangle assumes that industries correspond to 2 digit SIC industries, while the green square assumes that they correspond to 4 digit SIC industries. In the latter case, the number reported is the elasticity of substitution at the 2 digit level, using a cross industry elasticity $\eta$ of 1 . For most industries, the two different estimates of the 2 digit level elasticity of substitution are very close to each other, and in fact cannot be distinguished in the figure. If we weigh each industry elasticity by the weight from equation (22) based upon its share of total manufacturing cost and capital share, the average 2 digit level elasticity under the assumption of 4 digit industries is .639, compared to .652 in our baseline assumption.

Figure 6 Elasticity of Substitution by 2 Digit Industry, 1987

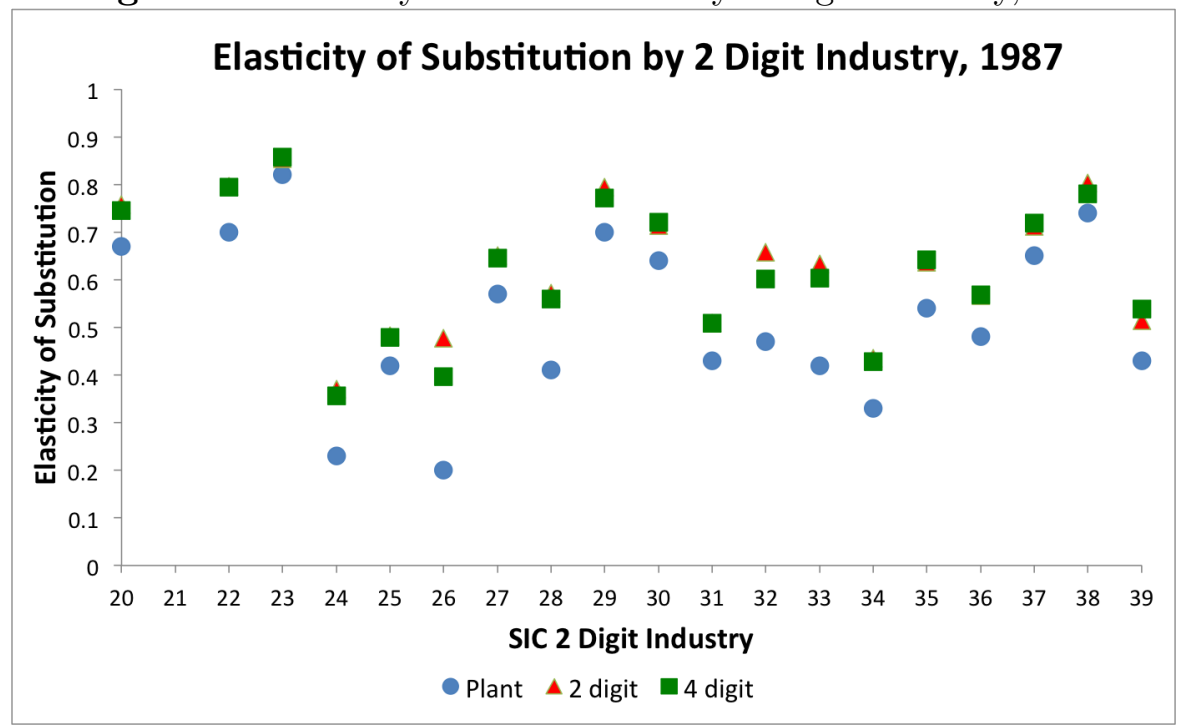

The plant level elasticity is the elasticity of substitution for 1987 for the 2 digit industry reported in Table III. The 2 digit elasticity of substitution computes the industry elasticity of substitution assuming that the relevant industries are at the 2 digit level. The 4 digit elasticity of substitution assumes that the relevant level of aggregation is the 4 digit industry, but reports an elasticity aggregated up to the 2 digit level using a cross industry elasticity of demand $\eta=1$. In either case, we use the 2 digit materials share from 1987 for each industry.

We now use equation (21) to characterize the overall manufacturing elasticity of substitution, 
maintaining the assumption of a cross industry elasticity of substitution $\eta$ is 1 . The overall manufacturing level elasticity of substitution of .672 using the 4 digit estimates,compared to .684 using the 2 digit estimates. We conclude that the our estimates are fairly insensitive to changes in industry definition.

\subsubsection{Alternative Estimation of the Elasticity of Demand}

For several industries, the US Census of Manufactures collects both price and physical quantity data in addition to revenue data. For these industries we can measure how quantity responds to changes in price without assuming optimal firm price setting, using an approach similar to Foster et al. (2008). We then compute the industry elasticity of substitution with these alternative parameters to assess the robustness of our original methodology.

To identify the demand function, we need an instrument that moves the supply curve independently of demand. We instrument using the average cost per unit of the plant, the plant specific sufficient statistic for productivity from our theory. We apply two sets of specifications: the first instruments with the average cost excluding materials and the second with the average cost including materials. Our regressions pool data from the 1987, 1992, and 1997 Censuses where we control for product-year fixed effects to allow the demand curve to shift over time as well as by product.

Table II shows the elasticities of demand for a set of products for which prices are available. Our estimates of the elasticity of demand for these products are between 1 and 3 , except for coffee which has higher elasticities. These estimates are similar to those in Foster et al. (2008), who also use data from 1977 and 1982 that allow them to examine a wider set of products.

We then examine how the industry level elasticity of substitution varies with different estimates of the elasticity of demand. Figure 7 displays the plant level elasticity of substitution calculated from plants within the product's 2 digit industry and two estimates of the industry level substitution elasticity. The first estimate uses demand elasticities from the IV estimation above with average non-materials cost as an instrument, while the second estimate uses our baseline demand elasticities from price-cost margins. The industry level elasticities of substitution are modestly higher than the plant level elasticities, ranging from $7 \%$ to $30 \%$ higher across products using the IV demand 
Table II Elasticity of Demand for Selected Products from IV Estimation

\begin{tabular}{|c|c|c|c|c|}
\hline Product & \multicolumn{2}{|c|}{ Elasticity of Demand } & $\begin{array}{c}\text { Number of Plants per } \\
\text { Year, Average from } \\
1987-1997\end{array}$ & $\begin{array}{c}\text { Estimates from } \\
\text { Foster, } \\
\text { Haltiwanger, } \\
\text { Syverson (2008) }\end{array}$ \\
\hline Boxes & $2.06(0.09)$ & $1.60(0.07)$ & $\sim 1000$ & $3.02(.17)$ \\
\hline Bread & $2.54(0.52)$ & $2.06(0.50)$ & $\sim 300$ & $3.09(.42)$ \\
\hline Coffee & $6.96(1.40)$ & $3.25(0.76)$ & $\sim 100$ & $3.63(.98)$ \\
\hline Concrete & 2.23 (0.22) & $1.80(0.18)$ & $\sim 2000$ & $5.93(.36)$ \\
\hline $\begin{array}{l}\text { Processed } \\
\text { Ice }\end{array}$ & $1.44(0.17)$ & $1.50(0.17)$ & $\sim 100$ & $1.48(.27)$ \\
\hline Plywood & $2.16(0.27)$ & $1.30(0.14)$ & $\sim 100$ & $1.21(.14)$ \\
\hline Instrument & $\begin{array}{c}\text { Plant Average } \\
\text { Cost, Excluding } \\
\text { Materials }\end{array}$ & $\begin{array}{c}\text { Plant Average } \\
\text { Cost, Including } \\
\text { Materials }\end{array}$ & & Plant Level TFP \\
\hline
\end{tabular}

Note: This table records the demand elasticity for selected products, calculated using IV regressions of log quantity on log price that control for product year fixed effects. We use two different instruments in the two specifications, the average cost (cost per unit of product produced) including materials cost and excluding materials cost.

elasticities. The industry level substitution elasticities are slightly higher when we use demand elasticities from price-cost margins, as these elasticities are usually higher. For these products, the average industry elasticity is .515 using the industry estimates from our IV regressions, .539 using the estimates in Foster et al. (2008), and .540 using the industry estimates from price-cost margins. Thus, these alternative estimates of the demand elasticity from IV estimation lead to similar aggregate substitution elasticities.

\subsection{The Direction of Aggregate Technical Change}

In the previous section, we found that the manufacturing level elasticity of substitution was less than one. Since the aggregate capital share has remained roughly constant, the direction of aggregate technical change must be labor augmenting in nature. We can further exploit the micro data 
Figure 7 Elasticities of Substitution for Homogenous Products

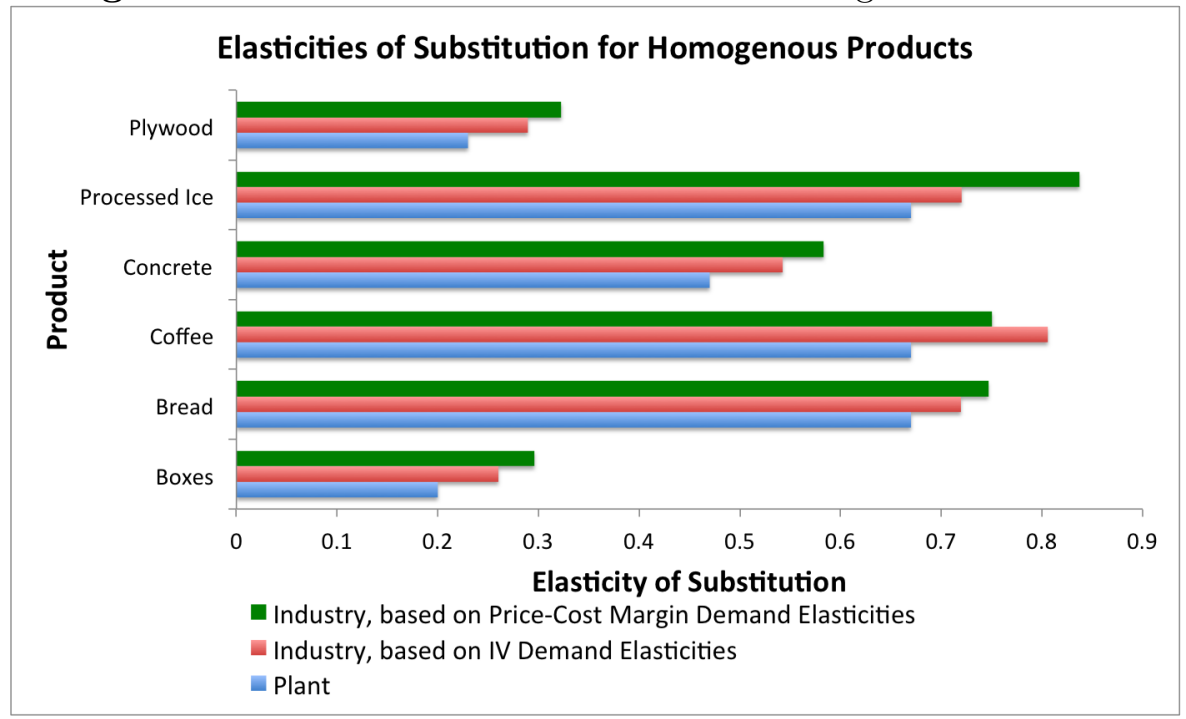

The plant level elasticity is the elasticity of substitution from 1987 for the 2 digit industry that the product belongs to reported in Table III. The industry elasticity of substitution based upon IV demand elasticities computes the industry elasticity of substitution from the elasticity of demand for that product calculated using the average non-materials cost in Table II, while the industry elasticity of substitution based upon price-cost margin demand elasticities does the same using elasticities of demand computed from inverting the average industry price cost margin. For the materials share, we use the average materials share for each product over Census years 1987, 1992, and 1997.

to examine the sources of this labor augmenting technical change, and how much of the bias in technical growth is due to within plant changes in technology. We answer these questions by applying the formulas in Section 2.4 to the US micro data, examining changes from 1987 to 1992 and 1992 to 1997. One important caveat applies: we currently maintain a fixed rental rate over time, though we are planning to relax this assumption.

We decompose the bias of technical change for an industry into the contribution from the bias of technical change within plants and changes in the composition of an industry due to neutral shifts in plants' scale. We can then decompose the aggregate bias of technical change into within and between industry components. If the cross-industry substitution parameter $\eta$ is one as we have assumed so far, this between industry component is zero as it is a multiple of $\eta-1$. When $\eta$ is one, industry revenue shares are fixed, so more capital intensive industries grow at the same rate 
as labor intensive industries. In any case, this cross industry term (before we multiply by $\eta-1$ ) is small in the 1987-1997 period, and is reported in Appendix G.

To calculate the micro components of the bias of technical change, we need the ratio of labor augmenting productivity to capital augmenting productivity $B_{i} / A_{i}$ at the plant level and neutral shifts that incorporate $A_{i}, B_{i}$, and $D_{i}$. We obtain the ratio of factor augmenting productivities $B_{i} / A_{i}$ from the the first order conditions. We can then capture $A_{i} D_{i}^{\frac{1}{\epsilon-1}}$ from the basic production function after inverting the demand function to separate out price and quantity. We keep the elasticity of substitution and elasticity of demand set to their 1987 values. Thus, we identify the relevant features of plant productivity and demand via the following formulas:

$$
\begin{gathered}
\log \left(B_{i} / A_{i}\right)=\log (w / r)+\frac{1}{1-\sigma} \log \left(\frac{r K}{w L}\right) \\
\log A_{i}+\frac{1}{\epsilon-1} \log D_{i}=\frac{\epsilon}{\epsilon-1} \log (P Y)-\frac{\sigma}{1-\sigma} \log \left(\frac{r K}{r K+w L}\right)-\log K
\end{gathered}
$$

We exclude entering and exiting plants from our calculations for any given five year time span. We can then compare the within plant component of the bias of technical growth to the between plant, within industry component. Figure 8 and Figure 9 depict the within plant and between plant components by 2 digit industry for the 1987-1992 period and the 1992-1997 periods. The within plant component is almost always positive (indicating labor augmenting technical change) and is far larger in magnitude than the between plant component for both periods. At the manufacturing level, the within plant component is .155 for 1987-1992 and .221 for 1992-1997, compared to a between plant component of -.023 for 1987-1992 and .0002 for 1992-1997. Thus, the growth in the bias of technical change is driven by within plant changes in technology. 


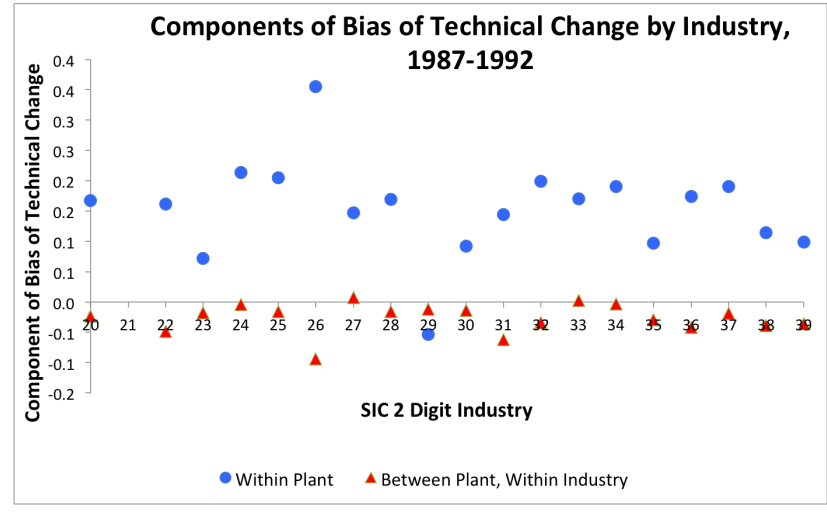

Figure 8 Components of Bias of Technical Change by 2 Digit Industry, 1987-1992

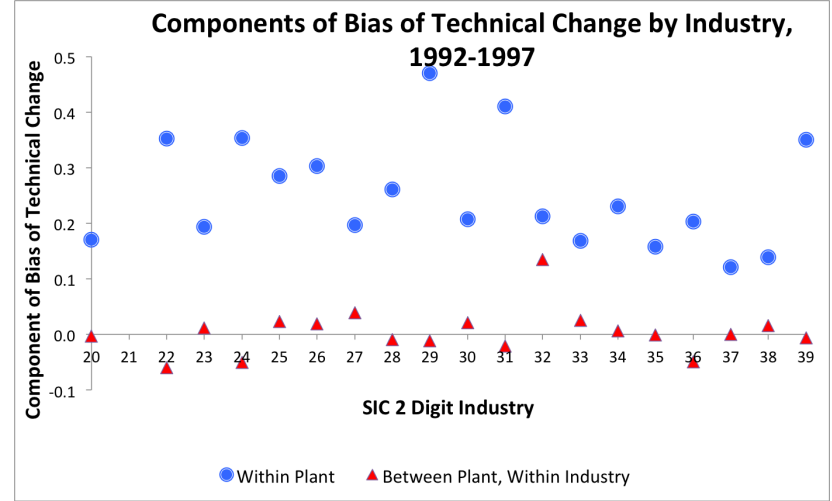

Figure 9 Components of Bias of Technical Change by 2 Digit Industry, 1992-1997

Note: The within plant component of the bias of technical change is the first term in equation (32), while the between plant, within industry component is the second term in equation (32).

\section{Conclusion}

This paper takes a bottom up approach to estimating the local elasticity of substitution between capital and labor for the US manufacturing sector. Accounting for substitution within and between plants, we show that the aggregate elasticity is a convex combination of the plant level elasticity of substitution and the elasticity of demand. We then estimate these plant level parameters for each industry. We show that the average 2 digit industry level elasticity of substitution is .65, most of which comes from substitution within plants. For the manufacturing sector as a whole, we estimate the elasticity of substitution between capital and labor to be roughly 0.68 .

So far, our estimates hold fixed the set of available technologies. In future work, we plan to incorporate the extensive margin as well.

An elasticity of substitution less than one is consistent with a roughly constant labor share of income when technological change is labor augmenting in aggregate. We decompose this aggregate bias in the direction of technological change into contributions from bias of changes at individual plants and from shifts in composition due to neutral changes in plants' scale from neutral productivity growth or shifts in demand. 
We find that biased technological growth at the plant level is the dominant source of the aggregate labor augmenting character of productivity growth, rather than shifts in composition. This fact suggests that changes in the distribution of productivity across plants may not be the driving force behind the constant aggregate labor share, and weakens support for theories that lean heavily on distributional assumptions to explain the roughly constant aggregate labor share, such as Houthakker (1955). 


\section{References}

Antras, Pol, "Is the US Aggregate Production Function Cobb-Douglas? New Estimates of the Elasticity of Substitution.," Contributions to Macroeconomics, 2004, 4 (1).

Arrow, Kenneth, H.B. Chenery, B. Minhas, and Robert M. Solow, "Capital-labor substitution and economic efficiency.," Review of Economics and Statistics, 1961, 43, 225-50.

Berndt, Ernst R., "Reconciling Alternative Estimates of the Elasticity of Substitution," Review of Economics and Statistics, 1976, 58 (1).

Diamond, Peter, Daniel McFadden, and Miguel Rodriguez, "Measurement of the Elasticity of Factor Substitution and Bias of Technical Change," in Melvyn Fuss and Daniel McFadden, eds., Production Economics: A Dual Approach to Theory and Applications, Vol. 2 of History of Economic Thought Chapters, McMaster University Archive for the History of Economic Thought, 1978, chapter 5 .

Fisher, Franklin M., "The Existence of Aggregate Production Functions," Econometrica, 1969, 37 (4), pp. 553-577.

- and John Monz, eds, Aggregation: Aggregate Production Functions and Related Topics, 1 ed., Vol. 1, The MIT Press, 1992.

Foster, Lucia, John Haltiwanger, and Chad Syverson, "Reallocation, Firm Turnover, and Efficiency: Selection on Productivity or Profitability?," American Economic Review, March 2008, $98(1), 394-425$.

Houthakker, H. S., "The Pareto Distribution and the Cobb-Douglas Production Function in Activity Analysis," The Review of Economic Studies, 1955, 23 (1), pp. 27-31.

Johansen, Leif, Production functions : an integration of micro and macro, short run and long run aspects, North Holland, 1972.

Jones, Chad, "The Shape of Production Functions and the Direction of Technical Change," Quarterly Journal of Economics, 2005, 120 (2).

Klump, R., P. McAdam, and A. Willman, "Factor Substitution and Factor Augmenting Technical Progress in the US," Review of Economics and Statistics, 2007, 89 (1).

Leon-Ledesma, Miguel A., Peter McAdam, and Alpo Willman, "Identifying the Elasticity of Substitution with Biased Technical Change," The American Economic Review, 2010, 100 (4), $1330-1357$.

Levhari, David, "A Note on Houthakker's Aggregate Production Function in a Multifirm Industry," Econometrica, 1968, 36 (1), pp. 151-154. 
Lucas, Robert, "Capital-Labor Substitution in U.S. Manufacturing," in A. C. Harberger and M. J. Bailey, eds., The Taxation of Income from Capital, Washington: Brookings Institution, 1969, pp. 223-274.

Luttmer, Erzo G. J., "Growth with a Fixed Factor," 2011. Mimeo.

Raval, Devesh, "Estimation of a CES Production Function with Factor Augmenting Technology," 2011. Mimeo.

Sato, Kazuo, "A Two-Level Constant-Elasticity-of-Substitution Production Function," The Review of Economic Studies, 1967, 34 (2), 201-218. 


\section{Appendix}

\section{A Proofs of Propositions}

\section{A.1 Industry Elasticity of Substitution: General Case}

Here we derive a formula for the elasticity of substitution given in equation (2) The formula in equation (1) is a special case.

We first assume that (i) each firm produces with a constant returns to scale production function, (ii) each firm minimizes cost, and (iii) face competitive factor markets. We later specialize to the case in which firm's maximize profit and face isoelastic demand curves.

Claim 1 Cost minimization, constant returns to scale, and competitive factor markets imply

$$
\bar{\sigma}_{n}^{N}=(1-\chi) \bar{\sigma}_{n}+\sum_{i \in I_{n}} \sum_{j \in I_{n}} \frac{d \ln \left(Y_{j} / Y_{i}\right)}{d \ln (r / w)} \frac{L_{j}}{L_{n}} \frac{K_{i}}{K_{n}}
$$

Proof. First, constant returns to scale along with Shephard's lemma imply that $\frac{d \ln \left(\lambda_{i} / w\right)}{d \ln (r / w)}=\alpha_{i}$ so that

$$
\frac{d \ln \left(\lambda_{i} / \lambda_{j}\right)}{d \ln (r / w)}=\alpha_{i}-\alpha_{j}
$$

Second, note that

$$
\frac{d \ln \left[\left(\frac{r}{w} \frac{K_{i}}{L_{i}}+1\right) /\left(\frac{r}{w} \frac{K_{j}}{L_{j}}+1\right)\right]}{d \ln (r / w)}=\alpha_{i}\left(1-\sigma_{i}\right)-\alpha_{j}\left(1-\sigma_{j}\right)
$$

Third, we can write the total cost to firm $i$ as $\lambda_{i} Y_{i}=r K_{i}+w L_{i}$. Dividing by the analogous expression for $j$, taking logs and differentiating gives

$$
\frac{d \ln \left(Y_{i} / Y_{j}\right)}{d \ln (r / w)}+\frac{d \ln \left(\lambda_{i} / \lambda_{j}\right)}{d \ln (r / w)}=\frac{d \ln \left(L_{i} / L_{j}\right)}{d \ln (r / w)}+\frac{d \ln \left[\left(\frac{r}{w} \frac{K_{i}}{L_{i}}+1\right) /\left(\frac{r}{w} \frac{K_{j}}{L_{j}}+1\right)\right]}{d \ln (r / w)}
$$

Solving for $\frac{d \ln \left(L_{i} / L_{j}\right)}{d \ln (r / w)}$ and using equation (37) and equation (38) gives

$$
\frac{d \ln \left(L_{i} / L_{j}\right)}{d \ln (r / w)}=\frac{d \ln \left(Y_{i} / Y_{j}\right)}{d \ln (r / w)}+\left[\alpha_{i} \sigma_{i}-\alpha_{j} \sigma_{j}\right]
$$


With this, the change in firm $i$ 's share of total labor can be written as

$$
\begin{aligned}
d \ln \left(\frac{L_{i}}{L_{n}}\right) & =\sum_{j \in I_{n}} \frac{L_{j}}{L_{n}} d \ln \left(\frac{L_{i}}{L_{j}}\right) \\
& =\sum_{j \in I_{n}} \frac{L_{j}}{L_{n}}\left\{\frac{d \ln \left(Y_{i} / Y_{j}\right)}{d \ln (r / w)}+\left(\alpha_{i} \sigma_{i}-\alpha_{j} \sigma_{j}\right)\right\}
\end{aligned}
$$

To compute the industry elasticity, we will use the following expression:

$$
\sum_{i \in I_{n}} \sum_{j \in I_{n}}\left[\alpha_{i} \sigma_{i}-\alpha_{j} \sigma_{j}\right] \frac{L_{j}}{L_{n}} \frac{K_{i}}{K_{n}}=\sum_{i \in I_{n}} \alpha_{i} \sigma_{i} \frac{K_{i}}{K_{n}}-\sum_{j \in I_{n}} \alpha_{j} \sigma_{j} \frac{L_{j}}{L_{n}}=\sum_{i \in I_{n}} \alpha_{i} \sigma_{i}\left(\frac{K_{i}}{K_{n}}-\frac{L_{i}}{L_{n}}\right)
$$

The industry elasticity of substitution $\sigma_{n}^{N}$ is then:

$$
\begin{aligned}
\sigma_{n}^{N} & =\sum_{i \in I_{n}} \sigma_{i} \frac{K_{i}}{K_{n}}-\sum_{i \in I_{n}} \frac{d \ln \left(L_{i} / L_{n}\right)}{d \ln (r / w)} \frac{K_{i}}{K_{n}} \\
& =\sum_{i \in I_{n}} \sigma_{i} \frac{K_{i}}{K_{n}}-\sum_{i \in I_{n}} \alpha_{i} \sigma_{i}\left(\frac{K_{i}}{K_{n}}-\frac{L_{i}}{L_{n}}\right)-\sum_{i \in I_{n}} \sum_{j \in I_{n}} \frac{d \ln \left(Y_{i} / Y_{j}\right)}{d \ln (r / w)} \frac{L_{j}}{L_{n}} \frac{K_{i}}{K_{n}}
\end{aligned}
$$

Combining the first two terms give

$$
\begin{aligned}
\sum_{i \in I_{n}}\left[\sigma_{i} \frac{K_{i}}{K_{n}}-\alpha_{i} \sigma_{i}\left(\frac{K_{i}}{K_{n}}-\frac{L_{i}}{L_{n}}\right)\right] & =\sum_{i \in I_{n}}\left[\frac{\alpha_{i}}{\alpha_{n}}-\alpha_{i}\left(\frac{\alpha_{i}}{\alpha_{n}}-\frac{1-\alpha_{i}}{1-\alpha_{n}}\right)\right] \sigma_{i} \frac{c_{i}}{c_{n}} \\
& =\sum_{i \in I_{n}} \frac{\alpha_{i}\left(1-\alpha_{i}\right)}{\alpha_{n}\left(1-\alpha_{n}\right)} \sigma_{i} \frac{c_{i}}{c_{n}} \\
& =\bar{\sigma}_{n} \sum_{i \in I_{n}} \frac{\alpha_{i}\left(1-\alpha_{i}\right)}{\alpha_{n}\left(1-\alpha_{n}\right)} \frac{c_{i}}{c_{n}} \\
& =(1-\chi) \bar{\sigma}_{n}
\end{aligned}
$$

where $\bar{\sigma}_{n}=\sum_{i \in I_{n}} \frac{\alpha_{i}\left(1-\alpha_{i}\right) c_{i}}{\sum_{j \in I_{n}} \alpha_{j}\left(1-\alpha_{j}\right) c_{j}} \sigma_{i}$.

Claim 2 If all firms maximize profit and face isoelastic demand with common demand elasticity $\varepsilon$ imply $\sum_{i \in I_{n}} \sum_{j \in I_{n}} \frac{d \ln \left(Y_{j} / Y_{i}\right)}{d \ln (r / w)} \frac{L_{j}}{L_{n}} \frac{K_{i}}{K_{n}}=\chi \varepsilon$.

Proof. With isoelastic demand, the profit maximizing price is $P_{i}=\frac{\varepsilon}{\varepsilon-1} \lambda_{i}$, and the profit maximizing quantity is $Y_{i}=D_{i}\left(\frac{\varepsilon}{\varepsilon-1}\right)^{-\varepsilon} \lambda_{i}^{-\varepsilon}$. We therefore have

$$
\frac{d \ln \left(Y_{j} / Y_{i}\right)}{d \ln (r / w)}=\varepsilon \frac{d \ln \left(\lambda_{i} / \lambda_{j}\right)}{d \ln (r / w)}=\varepsilon\left(\frac{d \ln \left(\lambda_{i} / w\right)}{d \ln (r / w)}-\frac{d \ln \left(\lambda_{j} / w\right)}{d \ln (r / w)}\right)=\varepsilon\left(\alpha_{i}-\alpha_{j}\right)
$$


This gives

$$
\begin{aligned}
\sum_{i \in I_{n}} \sum_{j \in I_{n}} \frac{d \ln \left(Y_{j} / Y_{i}\right)}{d \ln (r / w)} \frac{L_{j}}{L_{n}} \frac{K_{i}}{K_{n}} & =\varepsilon \sum_{i \in I_{n}} \sum_{j \in I_{n}}\left(\alpha_{i}-\alpha_{j}\right) \frac{L_{j}}{L_{n}} \frac{K_{i}}{K_{n}} \\
& =\varepsilon \sum_{i \in I_{n}} \alpha_{i}\left(\frac{K_{i}}{K_{n}}-\frac{L_{i}}{L_{n}}\right) \\
& =\varepsilon \sum_{i \in I_{n}} \alpha_{i}\left(\frac{\alpha_{i}}{\alpha_{n}}-\frac{1-\alpha_{i}}{1-\alpha_{n}}\right) \frac{c_{i}}{c_{n}} \\
& =\varepsilon \chi
\end{aligned}
$$

\section{A.2 The Bias of Technical Change}

Given the summary statistic for the state of technology and preferences $T$, we can compute how marginal cost changes over time.

$$
-\frac{\partial \ln \left(\lambda_{i}\right)}{\partial T}=\left(\frac{r / A_{i}}{\lambda_{i}}\right)^{1-\sigma} \frac{d \ln A_{i}}{d T}+\left(\frac{w / B_{i}}{\lambda_{i}}\right)^{1-\sigma} \frac{d \ln B_{i}}{d T}=\alpha_{i} \frac{d \ln A_{i}}{d T}+\left(1-\alpha_{i}\right) \frac{d \ln B_{i}}{d T}
$$

We can also compute the bias in technical change and growth in cost for a firm

$$
\begin{aligned}
\phi_{i} & =\frac{\partial \ln \left(\frac{K_{i}}{L_{i}}\right)}{\partial T} d T=(\sigma-1)\left(\frac{d \ln A_{i}}{d T}-\frac{d \ln B_{i}}{d T}\right) d T \\
g_{i} & =\frac{\partial \ln \lambda_{i} Y_{i}}{\partial T} d T=\frac{\partial \ln D_{i} \lambda_{i}^{1-\varepsilon}}{T} d T=\frac{d \ln D_{i}}{d T} d T+(1-\varepsilon) \frac{\partial \ln \lambda_{i}}{\partial T} d T \\
& =\frac{d \ln D_{i}}{d T} d T+(\varepsilon-1)\left(\alpha_{i} \frac{d \ln A_{i}}{d T}+\left(1-\alpha_{i}\right) \frac{d \ln B_{i}}{d T}\right) d T
\end{aligned}
$$

At the industry level we have

$$
\begin{aligned}
\phi_{n}^{N} & =d \ln K_{n} / L_{n}+\sigma_{n}^{N} d \ln r / w \\
& =\frac{\partial \ln K_{n} / L_{n}}{\partial T} d T+\frac{\partial \ln K_{n} / L_{n}}{\partial \ln r / w} d \ln r / w+\sigma_{n}^{N} d \ln r / w \\
& =\frac{\partial \ln K_{n} / L_{n}}{\partial T} d T
\end{aligned}
$$

By the same logic as above, we have

$$
d \ln \left(\sum_{i \in I_{n}} \frac{K_{i}}{L_{i}} \frac{L_{i}}{L_{n}}\right)=\sum_{i \in I_{n}} d \ln \left(K_{i} / L_{i}\right) \frac{K_{i}}{K_{n}}+\sum_{i \in I_{n}} d \ln \left(L_{i} / L_{n}\right) \frac{K_{i}}{K_{n}}
$$


and

$$
d \ln \left(\lambda_{i} Y_{i} / \lambda_{j} Y_{j}\right)=d \ln \left(L_{i} / L_{j}\right)+d \ln \left[\left(\frac{r}{w} \frac{K_{i}}{L_{i}}+1\right) /\left(\frac{r}{w} \frac{K_{j}}{L_{j}}+1\right)\right]
$$

Since $\frac{\partial \ln \left[\left(\frac{r}{w} \frac{K_{i}}{L_{i}}+1\right) /\left(\frac{r}{w} \frac{K_{j}}{L_{j}}+1\right)\right]}{\partial T} d T=\alpha_{i} \phi_{i}-\alpha_{j} \phi_{j}$ we have

$$
\frac{\partial \ln \left(L_{i} / L_{j}\right)}{\partial T} d T=\left(g_{i}-g_{j}\right)-\left(\alpha_{i} \phi_{i}-\alpha_{j} \phi_{j}\right)
$$

Next, we have

$$
\begin{aligned}
\frac{\partial \ln \left(L_{i} / L_{n}\right)}{\partial T} d T & =\sum_{j \in I_{n}} \frac{L_{j}}{L_{n}} \frac{\partial \ln \left(L_{i} / L_{j}\right)}{\partial T} d T \\
& =\sum_{j \in I_{n}} \frac{L_{j}}{L_{n}}\left[\left(g_{i}-g_{j}\right)-\left(\alpha_{i} \phi_{i}-\alpha_{j} \phi_{j}\right)\right]
\end{aligned}
$$

Using this, we have

$$
\begin{aligned}
& \sum_{i \in I_{n}}\left\{\sum_{j \in I_{n}} \frac{L_{j}}{L_{n}}\left[\left(g_{i}-g_{j}\right)-\left(\alpha_{i} \phi_{i}-\alpha_{j} \phi_{j}\right)\right]\right\} \frac{K_{i}}{K_{n}}=\sum_{i \in I_{n}}\left\{\sum_{j \in I_{n}} \frac{L_{j}}{L_{n}}\left[\left(g_{i}-\alpha_{i} \phi_{i}\right)-\left(g_{j}-\alpha_{j} \phi_{j}\right)\right]\right\} \frac{K_{i}}{K_{n}} \\
&=\sum_{i \in I_{n}}\left(g_{i}-\alpha_{i} \phi_{i}\right)\left(\frac{K_{i}}{K_{n}}-\frac{L_{i}}{L_{n}}\right) \\
& \phi_{n}^{N}=\sum_{i \in I_{n}} \phi_{i} \frac{K_{i}}{K_{n}}+\sum_{i \in I_{n}}\left(g_{i}-\alpha_{i} \phi_{i}\right)\left(\frac{K_{i}}{K_{n}}-\frac{L_{i}}{L_{n}}\right)
\end{aligned}
$$

The component with the bias terms $\left(\left\{\phi_{i}\right\}_{i \in I_{n}}\right)$ is

$$
\begin{aligned}
\sum_{i \in I_{n}} \phi_{i} \frac{K_{i}}{K_{n}}-\alpha_{i} \phi_{i}\left(\frac{K_{i}}{K_{n}}-\frac{L_{i}}{L_{n}}\right) & =\sum_{i \in I_{n}}\left[\frac{\alpha_{i}}{\alpha_{n}}-\alpha_{i}\left(\frac{\alpha_{i}}{\alpha_{n}}-\frac{1-\alpha_{i}}{1-\alpha_{n}}\right)\right] \phi_{i} \frac{c_{i}}{c_{n}} \\
& =\sum_{i \in I_{n}} \frac{\alpha_{i}\left(1-\alpha_{i}\right)}{\alpha_{n}\left(1-\alpha_{n}\right)} \phi_{i} \frac{c_{i}}{c_{n}} \\
& =\bar{\phi}_{n} \sum_{i \in I_{n}} \frac{\alpha_{i}\left(1-\alpha_{i}\right)}{\alpha_{n}\left(1-\alpha_{n}\right)} \frac{c_{i}}{c_{n}} \\
& =\bar{\phi}_{n}(1-\chi)
\end{aligned}
$$


The component with the growth terms $\left(\left\{g_{i}\right\}_{i \in I_{n}}\right)$ is

$$
\sum_{i \in I_{n}} g_{i}\left(\frac{K_{i}}{K_{n}}-\frac{L_{i}}{L_{n}}\right)=\sum_{i \in I_{n}}\left(\frac{\alpha_{i}-\alpha_{n}}{\alpha_{n}\left(1-\alpha_{n}\right)}\right) g_{i} \frac{c_{i}}{c_{n}}
$$

Putting these together, we get an expression for the industry bias:

$$
\phi_{n}^{N}=(1-\chi) \bar{\phi}_{n}+\sum_{i \in I_{n}}\left(\frac{\alpha_{i}-\alpha_{n}}{\alpha_{n}\left(1-\alpha_{n}\right)}\right) g_{i} \frac{c_{i}}{c_{n}}
$$

We can also compute an expression for the growth in industry cost:

$$
\begin{aligned}
g_{n}^{N} & ==\frac{\partial \ln \sum_{i \in I_{n}} \lambda_{i} Y_{i}}{\partial T}=\frac{\partial \ln \sum_{i} D_{i} \lambda_{i}^{1-\varepsilon}}{\partial T} \\
& =\sum_{i \in I_{n}}\left(\frac{\partial \ln D_{i}}{\partial T}+(1-\varepsilon) \frac{\partial \ln \lambda_{i}}{\partial T}\right) \frac{c_{i}}{c_{n}} \\
& =\sum_{i \in I_{n}} g_{i} \frac{c_{i}}{c_{n}}
\end{aligned}
$$




\section{B Elasticity of Substitution by 2 Digit Industry}

Table III Plant Level Elasticities of Substitution between Labor and Capital By Two Digit SIC Industry

\begin{tabular}{|c|c|c|c|c|c|}
\hline \multicolumn{6}{|c|}{ Level of Wage Variation } \\
\hline $\begin{array}{l}\text { SIC Two Digit } \\
\text { Industry: }\end{array}$ & $\begin{array}{c}\text { MSA Level, } \\
1987\end{array}$ & $\begin{array}{l}\text { MSA Level, } \\
1997\end{array}$ & $\begin{array}{c}\text { County } \\
\text { Level, } 1987\end{array}$ & $\begin{array}{c}\text { County } \\
\text { Level, } 1997\end{array}$ & $\begin{array}{l}\mathrm{N} \text { for } \\
1987\end{array}$ \\
\hline $\begin{array}{l}\text { 20: Food } \\
\text { Products }\end{array}$ & $\begin{array}{l}.67 \\
(.10)\end{array}$ & $\begin{array}{l}.87 \\
(.11)\end{array}$ & $\begin{array}{l}.71 \\
(.04)\end{array}$ & $\begin{array}{l}.81 \\
(.04)\end{array}$ & $\sim 10,000$ \\
\hline 22: Textiles & $\begin{array}{l}.70 \\
(.16) \\
\end{array}$ & $\begin{array}{l}.30 \\
(.24) \\
\end{array}$ & $\begin{array}{l}.70 \\
(.08) \\
\end{array}$ & $\begin{array}{l}.50 \\
(.07) \\
\end{array}$ & $\sim 3,500$ \\
\hline 23: Apparel & $\begin{array}{l}.82 \\
(.11)\end{array}$ & $\begin{array}{l}.40 \\
(.09)\end{array}$ & $\begin{array}{l}1.03 \\
(.04)\end{array}$ & $\begin{array}{l}.83 \\
(.03)\end{array}$ & $\sim 12,000$ \\
\hline $\begin{array}{c}\text { 24: Lumber and } \\
\text { Wood }\end{array}$ & $\begin{array}{l}.23 \\
(.12)\end{array}$ & $\begin{array}{l}.48 \\
(.11)\end{array}$ & $\begin{array}{l}.43 \\
(.04)\end{array}$ & $\begin{array}{l}.53 \\
(.04)\end{array}$ & $\sim 15,000$ \\
\hline 25: Furniture & $\begin{array}{l}.42 \\
(.14) \\
\end{array}$ & $\begin{array}{l}.18 \\
(.17) \\
\end{array}$ & $\begin{array}{c}.47 \\
(.05) \\
\end{array}$ & $\begin{array}{l}.49 \\
(.06) \\
\end{array}$ & $\sim 6,000$ \\
\hline 26: Paper & $\begin{array}{l}.20 \\
(.16)\end{array}$ & $\begin{array}{c}.20 \\
(.15)\end{array}$ & $\begin{array}{l}.46 \\
(.06)\end{array}$ & $\begin{array}{c}.61 \\
(.05)\end{array}$ & $\sim 4,000$ \\
\hline $\begin{array}{l}\text { 27: Printing and } \\
\text { Publishing }\end{array}$ & $\begin{array}{l}.57 \\
(.05)\end{array}$ & $\begin{array}{l}.50 \\
(.08)\end{array}$ & $\begin{array}{l}.69 \\
(.03)\end{array}$ & $\begin{array}{l}.66 \\
(.03)\end{array}$ & $\sim 26,000$ \\
\hline 28: Chemicals & $\begin{array}{l}.41 \\
(.15)\end{array}$ & $\begin{array}{l}.51 \\
(.21)\end{array}$ & $\begin{array}{c}.52 \\
(.08)\end{array}$ & $\begin{array}{l}.54 \\
(.08)\end{array}$ & $\sim 6,500$ \\
\hline $\begin{array}{l}\text { 29: Petroleum } \\
\text { Refining }\end{array}$ & $\begin{array}{l}.70 \\
(.23) \\
\end{array}$ & $\begin{array}{c}.53 \\
(.28) \\
\end{array}$ & $\begin{array}{l}.80 \\
(.11) \\
\end{array}$ & $\begin{array}{c}.81 \\
(.11) \\
\end{array}$ & $\sim 1,500$ \\
\hline 30: Rubber & $\begin{array}{c}.64 \\
(.13) \\
\end{array}$ & $\begin{array}{l}.42 \\
(.14) \\
\end{array}$ & $\begin{array}{c}.60 \\
(.05) \\
\end{array}$ & $\begin{array}{l}.59 \\
(.04) \\
\end{array}$ & $\sim 8,500$ \\
\hline 31: Leather & $\begin{array}{l}.43 \\
(.28)\end{array}$ & $\begin{array}{c}.46 \\
(.36)\end{array}$ & $\begin{array}{l}.88 \\
(.12)\end{array}$ & $\begin{array}{c}.99 \\
(.12)\end{array}$ & $\sim 1,000$ \\
\hline $\begin{array}{l}\text { 32: Stone, Clay, } \\
\text { Glass, Concrete }\end{array}$ & $\begin{array}{l}.47 \\
(.11) \\
\end{array}$ & $\begin{array}{c}.80 \\
(.16) \\
\end{array}$ & $\begin{array}{c}.64 \\
(.04) \\
\end{array}$ & $\begin{array}{c}.58 \\
(.05) \\
\end{array}$ & $\sim 9,000$ \\
\hline $\begin{array}{l}\text { 33: Primary } \\
\text { Metal }\end{array}$ & $\begin{array}{l}.42 \\
(.17)\end{array}$ & $\begin{array}{l}.26 \\
(.19)\end{array}$ & $\begin{array}{l}.69 \\
(.06)\end{array}$ & $\begin{array}{l}.67 \\
(.07)\end{array}$ & $\sim 4,000$ \\
\hline $\begin{array}{c}\text { 34: Fabricated } \\
\text { Metal }\end{array}$ & $\begin{array}{l}.33 \\
(.09)\end{array}$ & $\begin{array}{l}.25 \\
(.09)\end{array}$ & $\begin{array}{l}.56 \\
(.04)\end{array}$ & $\begin{array}{l}.59 \\
(.04)\end{array}$ & $\sim 20,000$ \\
\hline
\end{tabular}


Table 1. (contd)

\begin{tabular}{|c|c|c|c|c|c|}
\hline \multicolumn{6}{|c|}{ Level of Wage Variation } \\
\hline $\begin{array}{l}\text { SIC Two Digit } \\
\text { Industry: }\end{array}$ & $\begin{array}{c}\text { MSA Level, } \\
1987\end{array}$ & $\begin{array}{c}\text { MSA Level, } \\
1997\end{array}$ & $\begin{array}{c}\text { County } \\
\text { Level, } 1987\end{array}$ & $\begin{array}{c}\text { County } \\
\text { Level, } 1997\end{array}$ & $\begin{array}{l}\text { N for } \\
1987\end{array}$ \\
\hline 35: Machinery & $\begin{array}{l}.54 \\
(.08)\end{array}$ & $\begin{array}{l}.52 \\
(.11)\end{array}$ & $\begin{array}{c}.68 \\
(.02)\end{array}$ & $\begin{array}{l}.70 \\
(.03)\end{array}$ & $\sim 25,000$ \\
\hline $\begin{array}{c}\text { 36: Electrical } \\
\text { Machinery }\end{array}$ & $\begin{array}{c}.48 \\
(.12)\end{array}$ & $\begin{array}{c}.51 \\
(.12)\end{array}$ & $\begin{array}{c}.65 \\
(.07)\end{array}$ & $\begin{array}{l}.70 \\
(.05)\end{array}$ & $\sim 8,000$ \\
\hline $\begin{array}{c}37: \\
\text { Transportation } \\
\text { Equip }\end{array}$ & $\begin{array}{c}.65 \\
(.16)\end{array}$ & $\begin{array}{c}.77 \\
(.16)\end{array}$ & $\begin{array}{c}.70 \\
(.06)\end{array}$ & $\begin{array}{l}.75 \\
(.06)\end{array}$ & $\sim 5,000$ \\
\hline 38: Instruments & $\begin{array}{l}.74 \\
(.10)\end{array}$ & $\begin{array}{c}.71 \\
(.13)\end{array}$ & $\begin{array}{c}.67 \\
(.07)\end{array}$ & $\begin{array}{l}.74 \\
(.07)\end{array}$ & $\sim 4,500$ \\
\hline 39: Misc & $\begin{array}{c}.43 \\
(.13)\end{array}$ & $\begin{array}{c}.38 \\
(.12)\end{array}$ & $\begin{array}{c}.54 \\
(.04)\end{array}$ & $\begin{array}{l}.53 \\
(.05)\end{array}$ & $\sim 6,500$ \\
\hline $\begin{array}{c}\text { Source of Wage } \\
\text { Data }\end{array}$ & \multicolumn{2}{|c|}{ Census $5 \%$ individual samples } & \multicolumn{2}{|c|}{ Longitudinal Business Database } & \\
\hline Controls & \multicolumn{4}{|c|}{ Yes } & \\
\hline
\end{tabular}

Note: All regressions include industry dummies and have standard errors clustered at the two digit industry-area level (so for state-level regressions, two digit sic-state, etc.) Wages used are the average log wage for the geographic area, where the wage is computed as payroll/number of employees at the establishment level for the LBD wages and the wage is wage and salary income over total number of hours worked for the Census $5 \%$ sample data. The average log wages using worker data are adjusted for differences in education, experience, race, occupation, and industry. 


\section{Elasticity of Demand by 2 Digit Industry}

Table IV Elasticities of Demand from Price-Cost Margin by Two Digit SIC Industry

\begin{tabular}{|c|c|c|c|}
\hline \multirow{2}{*}{$\begin{array}{l}\text { SIC Two Digit } \\
\text { Industry: }\end{array}$} & \multicolumn{2}{|c|}{ Year } & \multirow{2}{*}{$\begin{array}{l}\mathrm{N} \text { for } \\
1987\end{array}$} \\
\hline & 1987 & 1997 & \\
\hline $\begin{array}{l}\text { 20: Food } \\
\text { Products }\end{array}$ & $\begin{array}{c}3.956 \\
(0.001)\end{array}$ & $\begin{array}{c}3.631 \\
\text { (0.002) }\end{array}$ & $\sim 10,000$ \\
\hline 22: Textiles & $\begin{array}{c}4.917 \\
(0.006)\end{array}$ & $\begin{array}{c}5.215 \\
(0.011)\end{array}$ & $\sim 3,500$ \\
\hline 23: Apparel & $\begin{array}{c}3.681 \\
(0.001)\end{array}$ & $\begin{array}{c}3.729 \\
(0.001)\end{array}$ & $\sim 12,000$ \\
\hline $\begin{array}{c}\text { 24: Lumber and } \\
\text { Wood }\end{array}$ & $\begin{array}{c}4.200 \\
(0.002)\end{array}$ & $\begin{array}{c}4.862 \\
(0.001)\end{array}$ & $\sim 15,000$ \\
\hline 25: Furniture & $\begin{array}{c}3.900 \\
(0.001)\end{array}$ & $\begin{array}{c}4.069 \\
\text { (0.002) }\end{array}$ & $\sim 6,000$ \\
\hline 26: Paper & $\begin{array}{c}4.730 \\
(0.003)\end{array}$ & $\begin{array}{c}4.576 \\
(0.003)\end{array}$ & $\sim 4,000$ \\
\hline $\begin{array}{l}\text { 27: Printing and } \\
\text { Publishing }\end{array}$ & $\begin{array}{c}3.197 \\
(0.001)\end{array}$ & $\begin{array}{c}3.531 \\
(0.001)\end{array}$ & $\sim 26,000$ \\
\hline 28: Chemicals & $\begin{array}{c}3.051 \\
(0.001)\end{array}$ & $\begin{array}{c}2.936 \\
(0.001)\end{array}$ & $\sim 6,500$ \\
\hline $\begin{array}{l}\text { 29: Petroleum } \\
\text { Refining }\end{array}$ & $\begin{array}{c}4.259 \\
(0.016)\end{array}$ & $\begin{array}{c}4.598 \\
(0.042)\end{array}$ & $\sim 1,500$ \\
\hline 30: Rubber & $\begin{array}{c}3.784 \\
(0.001) \\
\end{array}$ & $\begin{array}{c}3.634 \\
(0.001)\end{array}$ & $\sim 8,500$ \\
\hline 31: Leather & $\begin{array}{c}4.009 \\
(0.009)\end{array}$ & $\begin{array}{c}3.709 \\
(0.009)\end{array}$ & $\sim 1,000$ \\
\hline $\begin{array}{l}\text { 32: Stone, Clay, } \\
\text { Glass, Concrete }\end{array}$ & $\begin{array}{c}3.995 \\
(0.001)\end{array}$ & $\begin{array}{c}3.814 \\
(0.001)\end{array}$ & $\sim 9,000$ \\
\hline $\begin{array}{l}\text { 33: Primary } \\
\text { Metal }\end{array}$ & $\begin{array}{c}4.759 \\
(0.005)\end{array}$ & $\begin{array}{c}3.972 \\
(0.004)\end{array}$ & $\sim 4,000$ \\
\hline $\begin{array}{l}\text { 34: Fabricated } \\
\text { Metal }\end{array}$ & $\begin{array}{c}3.992 \\
(0.001)\end{array}$ & $\begin{array}{c}3.740 \\
(0.001)\end{array}$ & $\sim 20,000$ \\
\hline
\end{tabular}


Table 2: (contd)

\begin{tabular}{|c|c|c|c|}
\hline \multirow{2}{*}{$\begin{array}{l}\text { SIC Two Digit } \\
\text { Industry: }\end{array}$} & \multicolumn{2}{|c|}{ Year } & \multirow{2}{*}{$\begin{array}{l}\mathrm{N} \text { for } \\
1987\end{array}$} \\
\hline & 1987 & 1997 & \\
\hline 35: Machinery & $\begin{array}{c}3.932 \\
(0.001)\end{array}$ & $\begin{array}{c}3.817 \\
(0.001)\end{array}$ & $\sim 25,000$ \\
\hline $\begin{array}{c}\text { 36: Electrical } \\
\text { Machinery }\end{array}$ & $\begin{array}{c}3.449 \\
(0.001) \\
\end{array}$ & $\begin{array}{c}3.334 \\
(0.001)\end{array}$ & $\sim 8,000$ \\
\hline $\begin{array}{c}\text { 37: } \\
\text { Transportation } \\
\text { Equip }\end{array}$ & $\begin{array}{c}4.336 \\
(0.003)\end{array}$ & $\begin{array}{c}4.291 \\
(0.004)\end{array}$ & $\sim 5,000$ \\
\hline 38: Instruments & $\begin{array}{c}3.020 \\
(0.001)\end{array}$ & $\begin{array}{c}2.912 \\
(0.001)\end{array}$ & $\sim 4,500$ \\
\hline 39: Misc & $\begin{array}{c}3.582 \\
(0.001)\end{array}$ & $\begin{array}{c}3.429 \\
(0.001)\end{array}$ & $\sim 6,500$ \\
\hline
\end{tabular}

Note: This table records the demand elasticity for 2 digit industries, calculated by inverting the average price-cost margin. To calculate capital cost, we assume rental rates of $13.5 \%$ for equipment and $11 \%$ for structures for all manufacturing plants. 


\section{Materials Share of Cost for Selected Products and 2 Digit SIC Industries}

Table V Materials Share of Cost by Two Digit SIC Industry

\begin{tabular}{|c|c|c|c|}
\hline \multirow{2}{*}{$\begin{array}{c}\text { SIC Two Digit } \\
\text { Industry: }\end{array}$} & \multicolumn{2}{|c|}{ Year } & \multirow{2}{*}{$\begin{array}{l}\mathrm{N} \text { for } \\
1987\end{array}$} \\
\hline & 1987 & 1997 & \\
\hline $\begin{array}{l}\text { 20: Food } \\
\text { Products }\end{array}$ & 0.82 & 0.82 & $\sim 10,000$ \\
\hline 22: Textiles & 0.71 & 0.72 & $\sim 3,500$ \\
\hline 23: Apparel & 0.68 & 0.71 & $\sim 12,000$ \\
\hline $\begin{array}{l}\text { 24: Lumber and } \\
\text { Wood }\end{array}$ & 0.72 & 0.75 & $\sim 15,000$ \\
\hline 25: Furniture & 0.63 & 0.66 & $\sim 6,000$ \\
\hline 26: Paper & 0.69 & 0.68 & $\sim 4,000$ \\
\hline $\begin{array}{l}\text { 27: Printing and } \\
\text { Publishing }\end{array}$ & 0.54 & 0.56 & $\sim 26,000$ \\
\hline 28: Chemicals & 0.72 & 0.74 & $\sim 6,500$ \\
\hline $\begin{array}{l}\text { 29: Petroleum } \\
\text { Refining }\end{array}$ & 0.91 & 0.89 & $\sim 1,500$ \\
\hline 30: Rubber & 0.65 & 0.67 & $\sim 8,500$ \\
\hline 31: Leather & 0.69 & 0.72 & $\sim 1,000$ \\
\hline $\begin{array}{l}\text { 32: Stone, Clay, } \\
\text { Glass, Concrete }\end{array}$ & 0.62 & 0.62 & $\sim 9,000$ \\
\hline $\begin{array}{l}\text { 33: Primary } \\
\text { Metal }\end{array}$ & 0.68 & 0.72 & $\sim 4,000$ \\
\hline $\begin{array}{l}\text { 34: } \\
\text { Fabricated } \\
\text { Metal }\end{array}$ & 0.62 & 0.64 & $\sim 20,000$ \\
\hline
\end{tabular}


Table 2: (contd)

\begin{tabular}{|c|c|c|c|}
\hline \multirow{2}{*}{$\begin{array}{l}\text { SIC Two Digit } \\
\text { Industry: }\end{array}$} & \multicolumn{2}{|c|}{ Year } & \multirow{2}{*}{$\begin{array}{l}\mathrm{N} \text { for } \\
1987\end{array}$} \\
\hline & 1987 & 1997 & \\
\hline 35: Machinery & 0.60 & 0.69 & $\sim 25,000$ \\
\hline $\begin{array}{l}\text { 36: Electrical } \\
\text { Machinery }\end{array}$ & 0.61 & 0.65 & $\sim 8,000$ \\
\hline $\begin{array}{c}37: \\
\text { Transportation } \\
\text { Equip }\end{array}$ & 0.73 & 0.78 & $\sim 5,000$ \\
\hline 38: Instruments & 0.52 & 0.56 & $\sim 4,500$ \\
\hline 39: Misc & 0.64 & 0.65 & $\sim 6,500$ \\
\hline
\end{tabular}

Note: This table records the materials share of total cost for each 2 digit SIC industry, where we calculate capital costs using rental rates of $13.5 \%$ for equipment and $11 \%$ for structures.

Table VI Materials Share of Cost for Selected Products

\begin{tabular}{ccc}
\hline Product & $\begin{array}{c}\text { Average } \\
\text { Materials Share, } \\
1987-1997\end{array}$ & $\begin{array}{c}\text { Number of Plants per } \\
\text { Year, Average from } \\
1987-1997\end{array}$ \\
\hline Boxes & 0.76 & $\sim 1000$ \\
\hline Bread & 0.56 & $\sim 300$ \\
\hline Coffee & 0.82 & $\sim 100$ \\
\hline Concrete & 0.69 & $\sim 2000$ \\
\hline $\begin{array}{c}\text { Processed } \\
\text { Ice }\end{array}$ & 0.42 & $\sim 100$ \\
\hline Plywood & 0.75 & $\sim 100$ \\
\hline
\end{tabular}

Note: This table records the materials share of total cost for the underlying 4 digit industry of each product, where we calculate capital costs using rental rates of $13.5 \%$ for equipment and $11 \%$ for structures. 


\section{E Normalized Variance of Capital Shares for 2 digit SIC Indus- tries and Selected Products}

Table VII Normalized Variance of Capital Shares by Two Digit SIC Industry

\begin{tabular}{|c|c|c|c|c|c|c|c|}
\hline SIC Two Digit & & 1987 & & & 1997 & & $\mathrm{~N}$ for \\
\hline & $\begin{array}{l}\text { Within } 2 \\
\text { Digit }\end{array}$ & $\begin{array}{l}\text { Within } 4 \\
\text { Digit }\end{array}$ & $\begin{array}{l}\text { Between } 4 \\
\text { Digit, } \\
\text { Within } 2 \\
\text { Digit }\end{array}$ & $\begin{array}{l}\text { Within } 2 \\
\text { Digit }\end{array}$ & $\begin{array}{l}\text { Within } 4 \\
\text { Digit }\end{array}$ & $\begin{array}{l}\text { Between } 4 \\
\text { Digit, } \\
\text { Within } 2 \\
\text { Digit }\end{array}$ & \\
\hline $\begin{array}{l}\text { 20: Food } \\
\text { Products }\end{array}$ & 0.102 & 0.073 & 0.05 & 0.128 & 0.075 & 0.054 & $\sim 10,000$ \\
\hline 22: Textiles & 0.067 & 0.063 & 0.017 & 0.132 & 0.114 & 0.014 & $\sim 3,500$ \\
\hline 23: Apparel & 0.032 & 0.035 & 0.008 & 0.042 & 0.04 & 0.009 & $\sim 12,000$ \\
\hline $\begin{array}{l}\text { 24: Lumber and } \\
\text { Wood }\end{array}$ & 0.084 & 0.061 & 0.038 & 0.217 & 0.138 & 0.037 & $\sim 15,000$ \\
\hline 25: Furniture & 0.037 & 0.033 & 0.007 & 0.073 & 0.058 & 0.014 & $\sim 6,000$ \\
\hline 26: Paper & 0.142 & 0.076 & 0.074 & 0.215 & 0.114 & 0.099 & $\sim 4,000$ \\
\hline $\begin{array}{l}\text { 27: Printing and } \\
\text { Publishing }\end{array}$ & 0.056 & 0.051 & 0.007 & 0.082 & 0.078 & 0.008 & $\sim 26,000$ \\
\hline 28: Chemicals & 0.139 & 0.096 & 0.08 & 0.168 & 0.116 & 0.062 & $\sim 6,500$ \\
\hline $\begin{array}{l}\text { 29: Petroleum } \\
\text { Refining }\end{array}$ & 0.159 & 0.083 & 0.091 & 0.126 & 0.064 & 0.088 & $\sim 1,500$ \\
\hline 30: Rubber & 0.056 & 0.057 & 0.018 & 0.094 & 0.079 & 0.017 & $\sim 8,500$ \\
\hline 31: Leather & 0.053 & 0.048 & 0.013 & 0.086 & 0.079 & 0.014 & $\sim 1,000$ \\
\hline $\begin{array}{l}\text { 32: Stone, Clay, } \\
\text { Glass, Concrete }\end{array}$ & 0.112 & 0.065 & 0.052 & 0.193 & 0.133 & 0.043 & $\sim 9,000$ \\
\hline $\begin{array}{l}\text { 33: Primary } \\
\text { Metal }\end{array}$ & 0.12 & 0.087 & 0.069 & 0.123 & 0.095 & 0.06 & $\sim 4,000$ \\
\hline $\begin{array}{l}\text { 34: Fabricated } \\
\text { Metal }\end{array}$ & 0.058 & 0.05 & 0.014 & 0.078 & 0.067 & 0.022 & $\sim 20,000$ \\
\hline
\end{tabular}


Table 1: (contd)

\begin{tabular}{cccccccc}
\hline $\begin{array}{c}\text { SIC Two Digit } \\
\text { Industry: }\end{array}$ & \multicolumn{3}{c}{1987} & & 1997 & & $\begin{array}{c}\text { for } \\
1987\end{array}$ \\
\hline & $\begin{array}{c}\text { Within 2 } \\
\text { Digit }\end{array}$ & $\begin{array}{c}\text { Within 4 } \\
\text { Digit }\end{array}$ & $\begin{array}{c}\text { Between 4 } \\
\text { Digit, } \\
\text { Within } 2 \\
\text { Digit }\end{array}$ & $\begin{array}{c}\text { Within 2 } \\
\text { Digit }\end{array}$ & $\begin{array}{c}\text { Within 4 } \\
\text { Digit }\end{array}$ & $\begin{array}{c}\text { Between } 4 \\
\text { Digit, } \\
\text { Within 2 } \\
\text { Digit }\end{array}$ & \\
\hline $\begin{array}{c}\text { 35: Machinery } \\
\text { 36: Electrical } \\
\text { Machinery }\end{array}$ & 0.06 & 0.058 & 0.023 & 0.059 & 0.061 & 0.029 & $\sim 25,000$ \\
\hline $\begin{array}{c}\text { 37: } \\
\begin{array}{c}\text { Transportation } \\
\text { Equip }\end{array}\end{array}$ & 0.049 & 0.046 & 0.042 & 0.099 & 0.067 & 0.053 & $\sim 8,000$ \\
\hline 38: Instruments & 0.051 & 0.029 & 0.022 & 0.06 & 0.037 & 0.02 & $\sim 4,500$ \\
\hline 39: Misc & 0.056 & 0.061 & 0.035 & 0.089 & 0.075 & 0.031 & $\sim 6,500$ \\
\hline
\end{tabular}

Note: Each column is a different scaled weighted variance of capital shares. The within 2 digit and within 4 digit variances correspond to the capital share weight defined in equation (34) for all plants within a 2 digit and 4 digit industries respectively. To calculate capital cost, we assume rental rates of $13.5 \%$ for equipment and $11 \%$ for structures for all manufacturing plants. 
Table VIII Normalized Variance of Capital Shares for Selected Products

\begin{tabular}{lcc}
\hline Product & Normalized Capital Share Variance & $\begin{array}{c}\text { Number of Plants per } \\
\text { Year, Average from } \\
1987-1997\end{array}$ \\
\hline Boxes & 0.057 & $\sim 1000$ \\
\hline Bread & 0.049 & $\sim 300$ \\
\hline Coffee & 0.097 & $\sim 100$ \\
\hline Concrete & 0.080 & $\sim 2000$ \\
\hline Processed Ice & 0.086 & $\sim 100$ \\
\hline Plywood & 0.056 & $\sim 100$
\end{tabular}

Note: This table records the normalized variance of capital shares, using rental rates of $13.5 \%$ for equipment capital and $11 \%$ for structures capital and averaging over three Census years: 1987, 1992, and 1997.

\section{F 2 Digit Level Elasticity of Substitution}

Table IX 2 Digit Level Elasticities of Substitution between Labor and Capital

\begin{tabular}{cccccc}
\hline & \multicolumn{3}{c}{1987} & \multicolumn{3}{c}{1997} & \\
\hline $\begin{array}{c}\text { SIC Two Digit } \\
\text { Industry: }\end{array}$ & $\begin{array}{c}\text { 2 Digit } \\
\text { Estimate }\end{array}$ & $\begin{array}{c}\text { 4 Digit } \\
\text { Estimate }\end{array}$ & $\begin{array}{c}\text { 2 Digit } \\
\text { Estimate }\end{array}$ & $\begin{array}{c}\text { 4 Digit } \\
\text { Estimate }\end{array}$ & $\begin{array}{c}\text { N for } \\
1987\end{array}$ \\
\hline $\begin{array}{c}\text { 20: Food } \\
\text { Products }\end{array}$ & 0.76 & 0.75 & 0.95 & 0.92 & $\sim 10,000$ \\
\hline 22: Textiles & 0.80 & 0.79 & 0.55 & 0.52 & $\sim 3,500$ \\
\hline 23: Apparel & 0.85 & 0.86 & 0.46 & 0.46 & $\sim 12,000$ \\
\hline $\begin{array}{c}\text { 24: Lumber and } \\
\text { Wood }\end{array}$ & 0.37 & 0.36 & 0.80 & 0.70 & $\sim 15,000$ \\
\hline 25: Furniture & 0.48 & 0.48 & 0.32 & 0.30 & $\sim 6,000$ \\
\hline 26: Paper & 0.48 & 0.40 & 0.62 & 0.48 & $\sim 4,000$ \\
\hline $\begin{array}{c}\text { 27: Printing and } \\
\text { Publishing }\end{array}$ & 0.65 & 0.65 & 0.63 & 0.63 & $\sim 26,000$ \\
\hline 28: Chemicals & 0.57 & 0.56 & 0.68 & 0.65 & $\sim 6,500$ \\
\hline
\end{tabular}


Table 1. (contd)

\begin{tabular}{|c|c|c|c|c|c|}
\hline & \multicolumn{2}{|c|}{1987} & \multicolumn{2}{|c|}{1997} & \multirow[b]{2}{*}{$\mathrm{N}$ for } \\
\hline $\begin{array}{l}\text { SIC Two Digit } \\
\text { Industry: }\end{array}$ & $\begin{array}{l}2 \text { Digit } \\
\text { Estimate }\end{array}$ & $\begin{array}{l}4 \text { Digit } \\
\text { Estimate }\end{array}$ & $\begin{array}{l}2 \text { Digit } \\
\text { Estimate }\end{array}$ & $\begin{array}{l}4 \text { Digit } \\
\text { Estimate }\end{array}$ & \\
\hline $\begin{array}{l}\text { 29: Petroleum } \\
\text { Refining }\end{array}$ & 0.79 & 0.77 & 0.64 & 0.62 & $\sim 1,500$ \\
\hline 30: Rubber & 0.71 & 0.72 & 0.56 & 0.54 & $\sim 8,500$ \\
\hline 31: Leather & 0.51 & 0.51 & 0.57 & 0.57 & $\sim 1,000$ \\
\hline $\begin{array}{l}\text { 32: Stone, Clay, } \\
\text { Glass, Concrete }\end{array}$ & 0.66 & 0.60 & 1.04 & 0.97 & $\sim 9,000$ \\
\hline $\begin{array}{l}\text { 33: Primary } \\
\text { Metal }\end{array}$ & 0.63 & 0.60 & 0.45 & 0.45 & $\sim 4,000$ \\
\hline $\begin{array}{c}\text { 34: } \text { Fabricated } \\
\text { Metal }\end{array}$ & 0.43 & 0.43 & 0.39 & 0.38 & $\sim 20,000$ \\
\hline
\end{tabular}


Table 1. (contd)

\begin{tabular}{cccccc}
\hline & \multicolumn{3}{c}{1987} & \multicolumn{3}{c}{1997} & \\
\hline $\begin{array}{c}\text { SIC Two Digit } \\
\text { Industry: }\end{array}$ & $\begin{array}{c}2 \text { Digit } \\
\text { Estimate }\end{array}$ & $\begin{array}{c}\text { 4 Digit } \\
\text { Estimate }\end{array}$ & $\begin{array}{c}\text { 2 Digit } \\
\text { Estimate }\end{array}$ & $\begin{array}{c}\text { 4 Digit } \\
\text { Estimate }\end{array}$ & $\begin{array}{c}\text { N for } \\
1987\end{array}$ \\
\hline 35: Machinery & 0.64 & 0.64 & 0.60 & 0.61 & $\sim 25,000$ \\
\hline $\begin{array}{c}36: \text { Electrical } \\
\text { Machinery }\end{array}$ & 0.57 & 0.57 & 0.64 & 0.62 & $\sim 8,000$ \\
\hline $\begin{array}{c}37: \\
\begin{array}{c}\text { Transportation } \\
\text { Equip }\end{array}\end{array}$ & 0.71 & 0.72 & 0.84 & 0.84 & $\sim 5,000$ \\
\hline 38: Instruments & 0.80 & 0.78 & 0.78 & 0.76 & $\sim 4,500$ \\
\hline 39: Misc & 0.51 & 0.54 & 0.51 & 0.51 & $\sim 6,500$ \\
\hline
\end{tabular}

Note: The 2 digit estimate computes the industry elasticity of substitution assuming that 2 digit industries are the appropriate level of aggregation for industries. The 4 digit estimates uses the industry elasticity of substitution for the 4 digit level and then aggregates up to the 2 digit level. 


\section{G Composition of Bias of Technical Change}

Table X Composition of the Bias of Technical Change, 1987-1992 and 1992-1997

\begin{tabular}{|c|c|c|c|c|c|c|c|}
\hline \multirow{2}{*}{$\begin{array}{c}\text { SIC Two Digit } \\
\text { Industry: }\end{array}$} & \multicolumn{3}{|c|}{$1987-1992$} & \multicolumn{3}{|c|}{$1992-1997$} & \multirow{2}{*}{$\begin{array}{l}\mathrm{N} \text { for } \\
1987\end{array}$} \\
\hline & $\begin{array}{l}\text { Within } \\
\text { Firm }\end{array}$ & $\begin{array}{c}\text { Between } \\
\text { Firm, } \\
\text { Within } \\
\text { Industry }\end{array}$ & $\begin{array}{l}\text { Between } \\
\text { Industry }\end{array}$ & $\begin{array}{l}\text { Within } \\
\text { Firm }\end{array}$ & $\begin{array}{c}\text { Between } \\
\text { Firm, } \\
\text { Within } \\
\text { Industry }\end{array}$ & $\begin{array}{l}\text { Between } \\
\text { Industry }\end{array}$ & \\
\hline $\begin{array}{l}\text { 20: Food } \\
\text { Products }\end{array}$ & 0.167 & -0.024 & 0.003 & 0.170 & -0.003 & -0.060 & $\sim 10,000$ \\
\hline 22: Textiles & 0.162 & -0.048 & -0.017 & 0.352 & -0.060 & 0.000 & $\sim 3,500$ \\
\hline 23: Apparel & 0.072 & -0.017 & 0.000 & 0.194 & 0.012 & 0.004 & $\sim 12,000$ \\
\hline $\begin{array}{l}\text { 24: Lumber and } \\
\text { Wood }\end{array}$ & 0.214 & -0.004 & 0.015 & 0.353 & -0.050 & -0.050 & $\sim 15,000$ \\
\hline 25: Furniture & 0.205 & -0.016 & -0.004 & 0.285 & 0.023 & 0.003 & $\sim 6,000$ \\
\hline 26: Paper & 0.355 & -0.094 & -0.089 & 0.303 & 0.019 & -0.040 & $\sim 4,000$ \\
\hline $\begin{array}{l}\text { 27: Printing and } \\
\text { Publishing }\end{array}$ & 0.147 & 0.007 & 0.000 & 0.197 & 0.039 & -0.006 & $\sim 26,000$ \\
\hline 28: Chemicals & 0.169 & -0.016 & -0.024 & 0.261 & -0.009 & -0.027 & $\sim 6,500$ \\
\hline $\begin{array}{l}\text { 29: Petroleum } \\
\text { Refining }\end{array}$ & -0.053 & -0.012 & 0.038 & 0.470 & -0.011 & -0.017 & $\sim 1,500$ \\
\hline 30: Rubber & 0.092 & -0.014 & -0.003 & 0.207 & 0.022 & -0.005 & $\sim 8,500$ \\
\hline 31: Leather & 0.144 & -0.062 & -0.008 & 0.410 & -0.021 & -0.030 & $\sim 1,000$ \\
\hline $\begin{array}{l}\text { 32: Stone, Clay, } \\
\text { Glass, Concrete }\end{array}$ & 0.199 & -0.035 & -0.015 & 0.213 & 0.135 & 0.053 & $\sim 9,000$ \\
\hline $\begin{array}{c}\text { 33: Primary } \\
\text { Metal }\end{array}$ & 0.170 & 0.003 & -0.012 & 0.168 & 0.026 & 0.018 & $\sim 4,000$ \\
\hline $\begin{array}{l}\text { 34: Fabricated } \\
\text { Metal }\end{array}$ & 0.190 & -0.003 & 0.004 & 0.230 & 0.006 & -0.003 & $\sim 20,000$ \\
\hline
\end{tabular}


Table 1: (contd)

\begin{tabular}{|c|c|c|c|c|c|c|c|}
\hline \multirow{2}{*}{$\begin{array}{l}\text { SIC Two Digit } \\
\text { Industry: }\end{array}$} & \multicolumn{3}{|c|}{$1987-1992$} & \multicolumn{3}{|c|}{ 1992-1997 } & \multirow{2}{*}{$\begin{array}{l}\mathrm{N} \text { for } \\
1987\end{array}$} \\
\hline & $\begin{array}{l}\text { Within } \\
\text { Firm }\end{array}$ & $\begin{array}{l}\text { Between } \\
\text { Firm, } \\
\text { Within } \\
\text { Industry }\end{array}$ & $\begin{array}{l}\text { Between } \\
\text { Industry }\end{array}$ & $\begin{array}{l}\text { Within } \\
\text { Firm }\end{array}$ & $\begin{array}{l}\text { Between } \\
\text { Firm, } \\
\text { Within } \\
\text { Industry }\end{array}$ & $\begin{array}{l}\text { Between } \\
\text { Industry }\end{array}$ & \\
\hline 35: Machinery & 0.097 & -0.029 & -0.008 & 0.158 & -0.001 & 0.000 & $\sim 25,000$ \\
\hline $\begin{array}{l}\text { 36: Electrical } \\
\text { Machinery }\end{array}$ & 0.174 & -0.042 & 0.018 & 0.203 & -0.050 & 0.038 & $\sim 8,000$ \\
\hline $\begin{array}{c}37: \\
\text { Transportation } \\
\text { Equip }\end{array}$ & 0.190 & -0.018 & 0.009 & 0.121 & 0.000 & 0.016 & $\sim 5,000$ \\
\hline 38: Instruments & 0.114 & -0.039 & -0.007 & 0.139 & 0.016 & -0.080 & $\sim 4,500$ \\
\hline 39: Misc & 0.099 & -0.036 & 0.020 & 0.350 & -0.006 & -0.013 & $\sim 6,500$ \\
\hline $\begin{array}{c}\text { Manufacturing } \\
\text { Aggregate }\end{array}$ & 0.155 & -0.023 & -0.004 & 0.221 & 0.0002 & -0.012 & \\
\hline
\end{tabular}

Note: The within plant component of the bias of technical change is the first term in equation (32), the between plant, within industry component is the second term in equation (32), and the between industry component is the third term in equation (32) except the $\eta-1$ term, for changes from 1987-1992 and 1992-1997. 